\title{
An Overview on Catalytic Hydrodeoxygenation of Pyrolysis Oil and Its Model Compounds
}

\author{
Zhan Si ${ }^{1,2,3}$, Xinghua Zhang ${ }^{2}$, Chenguang Wang ${ }^{2, *}$, Longlong Ma ${ }^{2}$ and Renjie Dong ${ }^{1,3,4}$ \\ 1 Bioenergy and Environment Science \& Technology Laboratory, College of Engineering, \\ China Agricultural University, No. 17 Qinghua Donglu, Haidian District, Beijing 100083, China; \\ sizhan43@126.com (Z.S.); rjdong@cau.edu.cn (R.D.) \\ 2 Key Laboratory of Renewable Energy, Guangzhou Institute of Energy Conversion, Chinese Academy of \\ Sciences, Guangzhou 510640, China; zhangxh@ms.giec.ac.cn (X.Z.); mall@ms.giec.ac.cn (L.M.) \\ 3 Key Laboratory of Clean Production and Utilization Technology for Renewable Energy, \\ Ministry of Agriculture, College of Engineering, China Agricultural University, Beijing 100083, China \\ 4 National Center for International Research of BioEnergy Science and Technology, Ministry of Science and \\ Technology, China, Beijing 100083, China \\ * Correspondence: wangcg@ms.giec.ac.cn; Tel.: +86-20-37029721
}

Academic Editor: Yu-Chuan Lin

Received: 9 April 2017; Accepted: 15 May 2017; Published: 1 June 2017

\begin{abstract}
Pyrolysis is considered the most promising way to convert biomass to fuels. Upgrading biomass pyrolysis oil is essential to produce high quality hydrocarbon fuels. Upgrading technologies have been developed for decades, and this review focuses on the hydrodeoxygenation (HDO). In order to declare the need for upgrading, properties of pyrolysis oil are firstly analyzed, and potential analysis methods including some novel methods are proposed. The high oxygen content of bio-oil leads to its undesirable properties, such as chemical instability and a strong tendency to re-polymerize. Acidity, low heating value, high viscosity and water content are not conductive to making bio-oils useful as fuels. Therefore, fast pyrolysis oils should be refined before producing deoxygenated products. After the analysis of pyrolysis oil, the HDO process is reviewed in detail. The HDO of model compounds including phenolics monomers, dimers, furans, carboxylic acids and carbohydrates is summarized to obtain sufficient information in understanding HDO reaction networks and mechanisms. Meanwhile, investigations of model compounds also make sense for screening and designing HDO catalysts. Then, we review the HDO of actual pyrolysis oil with different methods including two-stage treatment, co-feeding solvents and in-situ hydrogenation. The relative merits of each method are also expounded. Finally, HDO catalysts are reviewed in order of time. After the summarization of petroleum derived sulfured catalysts and noble metal catalysts, transitional metal carbide, nitride and phosphide materials are summarized as the new trend for their low cost and high stability. After major progress is reviewed, main problems are summarized and possible solutions are raised.
\end{abstract}

Keywords: biomass; pyrolysis oil; hydrodeoxygenation; catalysts

\section{Introduction}

Rapid economic development remarkably increases the energy demand, especially in transportation fuels. Environmental concerns and uneven distribution of fossil fuel resources have aroused interest in developing renewable sources. Progress in technology of converting renewable sources into energy and fuels has become a research highlight. Biomass, as the only renewable organic carbon source feedstock, is a suitable renewable feedstock that can be converted into chemicals and transportation fuels [1,2]. Fast pyrolysis is a promising way to convert solid biomass to liquid products 
due to its high economic efficiency [3]. Different lignocellulosic biomass resources, including energy crops, forest waste residues, herbaceous and woody biomass, were studied to produce bio-oil through fast pyrolysis. Bio-oil generally contains 50-65 wt \% organic components, involving acids, aldehydes, ketones, furans, phenolics, guaiacols, syringols and sugars; $15-30 \mathrm{wt} \%$ moisture; and $20 \mathrm{wt} \%$ colloidal fraction [4]. Oxygens contained in these compounds cause undesirable properties such as low energy density, instability, high viscosity and corrosion. Therefore, removing redundant oxygen atoms is required for bio-oil upgrading. In the past decades, oxygen removal attracted researchers' attention all over the world. Since the 1990s, enormous papers in biomass pyrolysis oil upgrading were published and many great review papers inspired researchers all over the world. Hydrotreating is an effective way to upgrade bio-oil, which removes oxygen through $\mathrm{HDO}$, generally at $400-773 \mathrm{~K}$ and high $\mathrm{H}_{2}$ partial pressure. Different catalysts were used in HDO to remove the oxygen atom in the molecules. In this paper, after a brief introduction about the properties of bio-oil, we mainly focus on the recent progress in catalytic HDO of bio-oil. With the rapid development of catalysts and upgrading technology, we hope this review can provide useful information and inspire ideas in producing high quality bio-oil.

\section{Characteristics of Pyrolysis Oils}

\subsection{Properties of Bio-Oil}

The elemental compositions of bio-oil and petroleum derived fuel are quite different, and the basic data are shown in Table 1. Normally, there is $15-30 \mathrm{wt} \%$ water in bio-oil, derived from the moisture in the feedstock and dehydration process during the pyrolysis. The existence of water lowers the heating value and flame temperature of bio-oil. On the other hand, water reduces the viscosity and enhances the fluidity. Due to relatively high amounts of carboxylic acids mainly formed from hemicellulose pyrolysis, bio-oil generally shows acidity with $\mathrm{pH}$ value between 2 and 4 , resulting in fatal problems in downstream utilization [5]. As shown in Table 1, the oxygen content of bio-oil can reach as high as $50 \%$. The presence of oxygen is the main difference between bio-oils and hydrocarbon fuels. Since the oxygen content is quite high, the heating value of bio-oil is much lower than that of conventional fuel (50\%). Bio-oil has a heating value of about $20 \mathrm{MJ} / \mathrm{kg}$ using lignocellulosic biomass as feedstock, while that of fossil fuel is $45.5 \mathrm{MJ} / \mathrm{kg}$. In addition, immiscibility with hydrocarbon fuels was also caused by the high oxygen content.

Table 1. Comparison between biomass derived bio-oil and diesel.

\begin{tabular}{ccccc}
\hline \multirow{2}{*}{ Property } & \multicolumn{3}{c}{ Bio-Oil } & \multirow{2}{*}{ Diesel [6] } \\
\cline { 2 - 4 } & Pine Saw Dust [7] & Eucalyptus [7] & Rice Husk [8] & \\
\hline Density (kg/L) & 1.206 & 1.229 & 1.14 & 0.84 \\
C (wt \%) & 40.6 & 42.3 & 39.92 & 86.58 \\
H (wt \%) & 7.6 & 7.5 & 8.15 & 13.29 \\
O (wt \%) & 51.7 & 50.1 & 51.11 & 0.01 \\
N (wt \%) & $<0.1$ & 0.1 & 0.61 & $65 \mathrm{ppm}$ \\
Ash & 0.03 & 0.03 & 0.25 & - \\
Viscosity (c St) & $17(313 \mathrm{~K})$ & $23(313 \mathrm{~K})$ & $13.2(313 \mathrm{~K})$ & $2.1(323 \mathrm{~K})$ \\
Moisture content (wt \%) & 23.9 & 20.6 & 28 & - \\
Higher heating value (MJ/kg) & 16.9 & 17.3 & 16.5 & 45.5 \\
PH & 2.7 & 2.2 & 3.2 & - \\
Flash point (K) & 326 & 374 & 341 & 327 \\
\hline
\end{tabular}

As can be seen in Table 1, the viscosity of bio-oil is much higher than the conventional fuel. Depending on the types of biomass, pyrolysis conditions and storage time, a wide range of the bio-oil viscosities are obtained. Sipilaè et al. found that the viscosities of bio-oils were reduced with higher water content and less water insoluble components [5]. Boucher et al. added methanol into bio-oil, finding that methanol reduced the density and viscosity and increased the stability. Moreover, the ash in bio-oil can cause problems in engines, such as corrosion, abrasion and deposition. Alkali and alkali 
earth metals are problematic components in the ash. The concentration of alkali and alkali earth metals in bio-oil are listed in Table 2. The concentrations are distinct when the bio-oils are produced from different feedstocks and conditions. The inorganic impurities in bio-oil could cause the catalyst poisoning during upgrading process. Yildiz et al. reported that an ash concentration of $3 \mathrm{wt} \%$ could have effect on the zeolite catalysts [9]. Kubička and Horáček found that phosphorus, alkali and alkali earth metal could cause deactivation of $\mathrm{CoMo} / \gamma-\mathrm{Al}_{2} \mathrm{O}_{3}$ [10]. Hot gas filtering is an efficient method to remove metallic heteroatoms in bio-oil. Scahill et al. employed hot gas filtration to decrease the alkali metal concentration below $10 \mathrm{ppm}$ [11]. The ash content of cassava stalk bio-oil decreased from $0.2 \%$ to $0.01 \%$ after using gas filter [12]. Baldwin and Feik reduced the concentration of $\mathrm{Ca}<10 \mathrm{ppm}$, $\mathrm{Mg}<1 \mathrm{ppm}, \mathrm{K}<5 \mathrm{ppm}$ and $\mathrm{Na}<5 \mathrm{ppm}$ by hot gas filtration with a ceramic filter element [13]. In order to understand where the ash come from and how it affect the bio-oil's properties, the existence form of alkali and alkaline metals in both biomass and pyrolysis vapor maybe more important.

Table 2. The concentration of alkali and alkali earth metals in bio-oil.

\begin{tabular}{cccc}
\hline $\begin{array}{c}\text { Alkali and Alkali Earth } \\
\text { Metals (ppm) }\end{array}$ & \multicolumn{3}{c}{ Bio-Oil } \\
\cline { 2 - 4 } & Rice Straw [14] & Bamboo [14] & Japanese Larch [15] \\
\hline $\mathrm{Na}$ & 46 & 16 & 4.2 \\
$\mathrm{~K}$ & 25 & 6 & $<0.1$ \\
$\mathrm{Ca}$ & 32 & 9 & 2.8 \\
$\mathrm{Mg}$ & 9 & 2 & 0.1 \\
\hline
\end{tabular}

\subsection{Compositions of Bio-Oil}

Insights in the composition of bio-oils are essential to determine its potential uses and the type of process required for upgrading methods [16]. Wang et al. used gas chromatography-mass spectrometer (GC/MS) to analyze the composition of bio-oils and illustrate that most of the identified components were phenolic compounds attached with ketones or aldehydes groups [17]. Therefore, bio-oils were highly hydrated, resulting in a difficult elimination of water. Conventional GC, especially when coupled with MS, is commonly used to analyze the chemical components for decades. However, GC-MS is not the most favorable technique for bio-oil characterization, as the poor elution properties of various compounds resulted in strong tail and coelution peaks. Comprehensive two-dimensional gas chromatography $(\mathrm{GC} \times \mathrm{GC})$ coupled with different detectors is a new method in bio-oil characterization. Coelutions in the 1 DGC could be resolved by GC $\times$ GC, thus the number of compounds identified using GC $\times$ GC was approximately 4-7 times greater than that using conventional GC [18]. However, only $25-40 \%$ of the analytes are detected because carbohydrates and lignin-derived oligomers are hard to evaporate which makes them difficult to enter the GC column [16]. Fourier transform ion cyclotron resonance mass spectrometry (FT-ICR MS) is able to characterize the nonvolatile compounds in bio-oils [19]. For pine pellets and peanut hull bio-oils characterized by FT-ICR MS, much lower oxygens per molecule was obtained in the oil phase than aqueous phase [20]. Red pine bio-oil was analyzed by FT-ICR MS coupled with negative ion electrospray ionization (ESI) source. The predominant compounds in bio-oil are O2-O17 class species with 1-22 double-bond equivalent (DBE) values and 4-39 carbon numbers. The $\mathrm{N}_{1} \mathrm{O}_{\mathrm{x}}$ was also identified, which involved 1-16 DBE and 6-30 carbon numbers [21]. NMR spectroscopy is also employed for the characterization of bio-oils, which can provide the concentrations of chemical functionalities and indications of highly substituted aromatic groups. For instance, the $13 \mathrm{C}$ and DEPT analyses showed that corn stover bio-oil is highly branched owing to the high percentage of $\mathrm{CH} 1$ groups and the aromatic region generally has $\mathrm{CH} 0: \mathrm{CH} 1$ ratios of $>2: 1$, suggesting that the average aromatic ring has at least four substituents. Additionally, high content of intact carbohydrate in corn stover bio-oil is demonstrated by $1 \mathrm{H}$ NMR analysis, because a relatively high concentration of protons was observed at $\sim 5 \mathrm{ppm}$ [22]. 
Thus, integrated techniques are generally employed to obtain a comprehensive characterization of bio-oil. Currently, GC $\times$ GC combined with HRMS (using different ionization methods) seem to be most promising to obtain a specific chemical characterization of bio-oils. Spectroscopic method is also crucial as it enables to provide the bio-oils composition profile assessment [23].

\section{HDO}

As discussed earlier, some undesirable properties of bio-oil, such as chemical instability and a strong tendency to re-polymerize are caused by the high oxygen content. High viscosities, acidity, water content and low heating value are all major defects making it very hard to use bio-oils as fuels. Therefore, fast pyrolysis oils must be refined to produce deoxygenated products that are compatible with existing transportation fuels.

The general methods for bio-oil upgrading include physical, chemical and catalytic process. Physical upgrading includes filtration, solvent addition and emulsion. Liquid filtration is extremely difficult because of the physicochemical properties of bio-oil, while hot-vapor filtration can lower the average molecular weight of the liquid product and improve its stability during accelerated aging studies [13]. For solvent addition and emulsion, solvents and surfactants are added into bio-oil to improve stability. Chemical upgrading mainly involves esterification, aqueous phase processing, mild cracking, gasification, etc. Catalytic upgrading pathways include HDO, zeolite cracking and steam reforming, of which the last one is a route to produce $\mathrm{H}_{2}$, not transportation fuel. Zeolite cracking is correlated with fluid catalytic cracking (FCC) of petroleum fractions, where oxygen atoms are removed by simultaneous dehydration-decarboxylation reactions over cracking catalysts (generally acidic zeolite) at atmospheric pressure without external $\mathrm{H}_{2}$. However, a major defect of this method is the low hydrocarbon yield due to severe carbonaceous deposits and dealumination of zeolite. Hydrotreating is also a conventional process for petroleum reforming, including hydrodesulfurization (HDS), hydrodenitrogenation (HDN), and HDO to remove sulfur, nitrogen, and oxygen heteroatoms respectively. Unlike petroleum oil, the content of sulfur and nitrogen in bio-oils is negligible whereas O content is extremely high. Hence, HDO becomes a crucial research topic. During HDO, reactions may occur including deoxygenation ( $\mathrm{C}-\mathrm{O}$ cleavage), hydrogenation (saturation of $\mathrm{C}=\mathrm{O}$ and aromatic rings), hydrogenolysis, hydrocracking, etc.

\subsection{HDO of Model Compounds}

The reaction pathway of bio-oil HDO is still not clear due to its complicated nature resulting in numerous concurrent reactions during the upgrading process. Therefore, rather than employing pyrolysis oil at lab-scale, most studies use model compounds to obtain sufficient information in order to understand HDO reaction networks and mechanisms. Meanwhile, model compounds experiments contribute to screening and designing HDO catalysts [24]. Currently, model compounds are selected among the most active compounds which will cause the instability of bio-oil. These compounds with different functional groups allow one to investigate the relative activities and selectivity of different reactions, such as dehydration, decarboxylation, hydrogenation, hydrogenolysis and hydrocracking. Furthermore, dimeric compounds were also selected as model compounds to provide an insight into the cleavage of some major types of linkage.

\subsubsection{HDO of Aromatic Monomers}

Since bio-oil contains almost $30 \mathrm{wt} \%$ of aromatic compound which has high energy density [25], a large amount of researches focus on HDO of these compounds. Additionally, the existence of phenolic compounds is considered as the primary cause for coke formation and catalyst deactivation [26]. Thus, conversion of these oxygen-contained aromatic compounds is important in bio-oil upgrading.

Phenol is widely investigated as a model compound in HDO process because of its simple structure. In accordance with numerous investigations, HDO of phenol undergoes two main parallel routes. The first route is direct deoxygenation (DDO) that leads to formation of benzene by the 
cleavage of C-O bond. The second is hydrogenation (HYD), in which the aromatic ring is hydrogenated to cyclohexanol. Subsequent hydrogenation of benzene or deoxygenation of cyclohexanol occurs, leading to the formation of cyclohexane. Meanwhile, alkylation and etherification take place to form bicyclic compounds. Hong et al. also reported similar reaction pathways of phenol to bicyclics over $\mathrm{Pt} / \mathrm{HY}$ catalyst [27]. Studies on both aqueous-phase and vapor-phase HDO of phenol indicated that non-sulfide catalysts favor HYD route to saturate the aromatic ring. For example, no aromatic hydrocarbons were produced in $\mathrm{HDO}$ of phenol over $\mathrm{Pd} / \mathrm{C}$ and $\mathrm{H}_{3} \mathrm{PO}_{4}$ at $523 \mathrm{~K}$ [25]. Therefore, $\mathrm{HDO}$ catalysts properties can significantly affect the reaction pathways.

Anisole with a methoxyl group is another model compound used for the study of bio-oil HDO. Figure 1 shows a general reaction scheme of anisole HDO studied by Sankaranarayanan et al. over supported $\mathrm{Ni}$ and Co catalyst, involving four reaction pathways: (1) demethylation of anisole to phenol and methane; (2) direct deoxygenation to benzene and methanol; (3) hydrogenation to methyl cyclohexyl ether; and (4) isomerization to methylphenol and dimethylphenol [28]. These primary products can be further converted to cyclohexane, cyclohexanol, methylcyclopentane, etc. Pichaikaran et al. studied the vapor-phase HDO of anisole over supported $\mathrm{Ni}$ and Ru catalysts atatmospheric pressure [29]. The major products obtained are phenol, benzene and toluene, indicating that the conversion of anisole mainly proceeds via hydrodeoxygenation, hydrogenolysis and methyl group transfer.

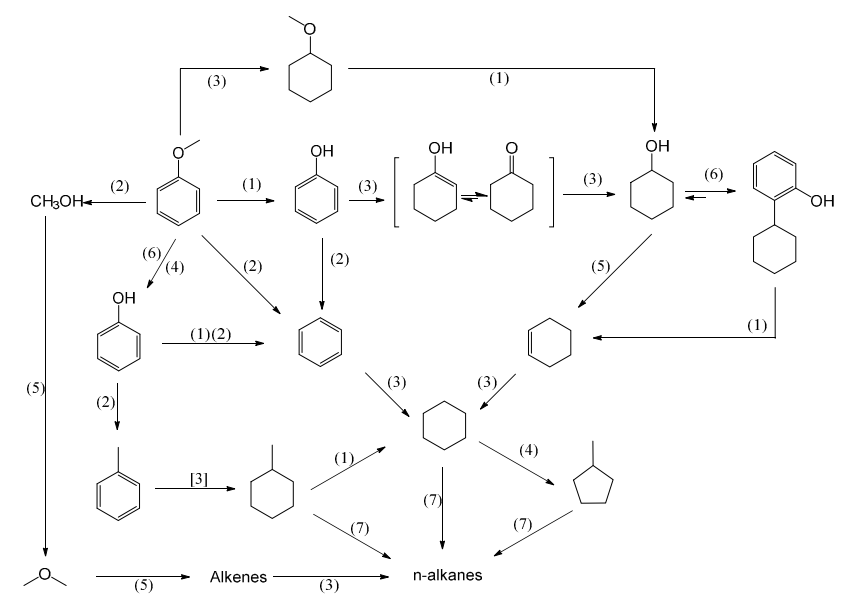

Figure 1. Reaction network for anisole HDO: (1) dealkylation and demethylation; (2) direct deoxygenation; (3) hydrogenation; (4) isomerization; (5) dehydration; (6) alkylation; and (7) ring opening reaction [28].

Guaiacol with two kinds of $\mathrm{C}-\mathrm{O}$ bond (hydroxyl group (-OH) and methoxy group $\left(-\mathrm{OCH}_{3}\right)$ ) appears to be an attractive compound for bio-oil HDO. The HDO scheme of guaiacol proposed by Nguyen et al. is shown in Figure 2, indicating that the reactions proceeded via demethylation, demethoxylation, hydrogenation and methyl transfer [30]. The results of numerous researches for guaiacol HDO with different catalyst indicated that the catalyst composition plays a significant role during the reaction. Zhao et al. studied vapor phase HDO of guaiacol catalyzed by supported metal phosphide. The formation of anisole demonstrated that dehydroxylation occurs as a new reaction pathway of guaiacol HDO. Meanwhile, the hydrogenation reaction did not take place under this condition since no saturated products were detected [31].

\subsubsection{HDO of Aromatic Dimers}

The water insoluble fraction, often known as pyrolytic lignin (PL), can account for $25-30 \%$ of the bio-oil [32]. The oligomeric PL portion is considered to be responsible for poor properties like viscosity and instability. Bayerbach et al. proposed several oligomeric structures of pyrolytic lignin that are based on combinations of phenolic dimers with different linkers [33]. Therefore, oligomers, 
especially phenolic dimers, were selected as model compounds to investigate the cleavage of typical linkages (e.g., $\beta-\mathrm{O}-4, \alpha-\mathrm{O}-4$, and $\beta-5$ ) during $\mathrm{HDO}$ process. Jongerius et al. studied $\mathrm{HDO}$ of phenolic dimers over a commercial sulfide $\mathrm{CoMo} / \mathrm{Al}_{2} \mathrm{O}_{3}$ catalyst at $573 \mathrm{~K}$ and 50 bar $\mathrm{H}_{2}$ pressure, revealing that ether linkages including $\beta-\mathrm{O}-4$ and phenylcoumaran can be broken under this condition, but not the $5-5^{\prime}$ linkage [34]. Zhang et al. tested HDO of a series of phenolic dimes with Ru/HZSM-5 at $473 \mathrm{~K}$ and 50 bar of $\mathrm{H}_{2}$ in a batch reactor. As shown in Table 3, conversions of all the model compounds almost achieved $100 \%$ and the overall selectivity to alkenes were above $96 \%$ except 2,2'-biphenol [35]. The 4-O-5 and $\alpha-\mathrm{O}-4$ dimers were quantitatively converted to cyclohexane and C6-C10 alkanes, respectively. The formation of C8-C10 alkanes during HDO of $\alpha-\mathrm{O}-4$ dimers started with acid catalyzed transalkylation of $\mathrm{C} 6-\mathrm{C} 7$ products, followed by the isomerization of substituted cyclohexanes on Brønsted acid sites. Ethylcyclohexane, the main product for HDO of $\beta-5$ dimers, was obtained by hydrogenation of aromatic ring followed by dehydration and hydrogenation reactions. One reason for the relatively low hydrogenation rate of $5-5^{\prime}$ dimer might be caused by its intramolecular hydrogen bonds that could hinder the attack of the catalyst. Parsell et al. used $\mathrm{Zn} / \mathrm{Pd} / \mathrm{C}$ catalyst for HDO of guaiacylglycerol-b-guaiacyl ether under relatively mild condition, $423 \mathrm{~K}$ and 20.7 bar hydrogen pressure, got complete conversion and yielded two main aromatic products [36]. The $\beta-\mathrm{O}-4$ linkage was effectively cleaved to aromatic fragments, and its alcohol oxygen on alkyl chains was subsequently removed with loss of aromatic groups. Strassberger et al. obtained phenol and ethylbenzene as main products in HDO of 2-phenoxy-1-phenylethanone and its alcohol analog on supported copper catalysts. The mechanism for HDO of alcohol dimer was proposed as the hydrogenolysis of C-O (aryl) bond occurred to phenol and 1-phenylethanol, followed by hydrodeoxygenation to ethylbenzene. The alcohol dimers were also catalyzed by alumina to form oligomers as by-products [37].

Table 3. Hydrodeoxygenation of Phenolic Dimers over Ru/HZSM-5 [35].

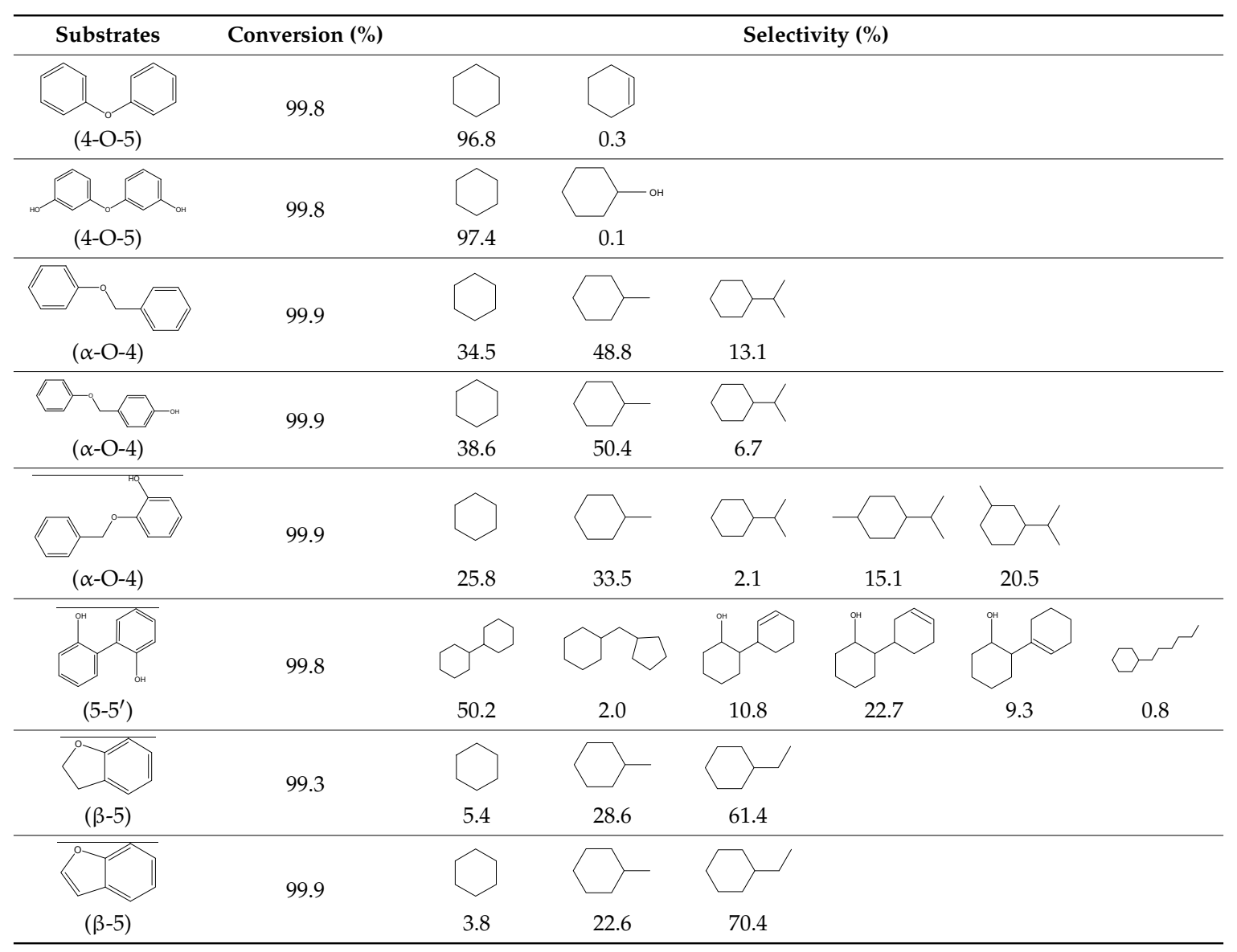




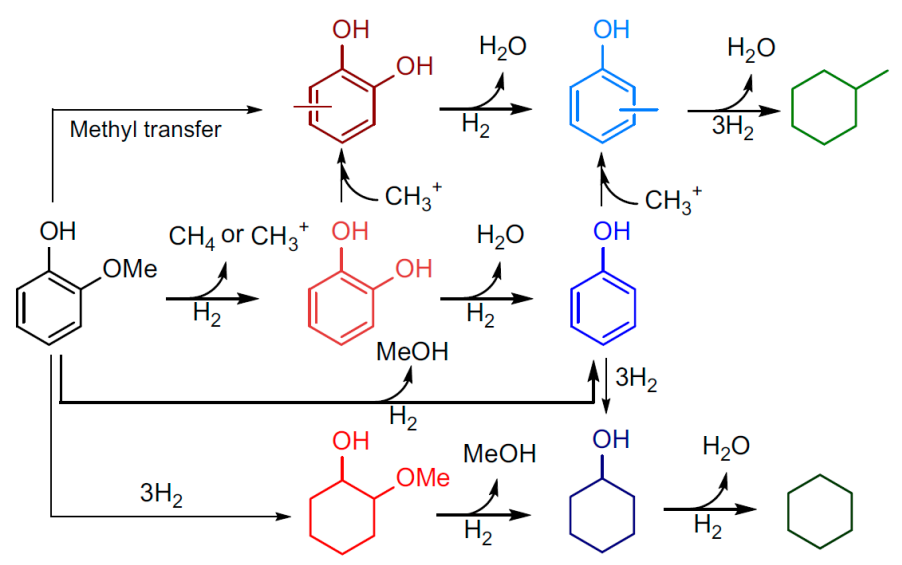

Figure 2. Possible pathways of guaiacol HDO [30].

\subsubsection{HDO of Other Oxygenates}

In addition to lignin-based aromatic oxygenates, furans, carboxylic acids, alcohols and carbohydrates are also common products in biomass pyrolysis. A number of investigations focused on HDO of these cellulosic or hemicellulosic fractions of biomass pyrolysis.

A hypothetical mechanism for furan HDO was proposed including two reaction routes. For one route, furan first formed a transition state, followed by the formation of butadiene which could further undergo hydrogenation to butane. Moreover, partial hydrogenation of the ring also occurred followed by ring opening to a new transition state, which subsequently decomposed to propylene or butylene [38]. Zheng et al. proposed a proper pathway for vapor-phase HDO of furfural over Cu-based catalyst, as shown in Figure 3 [39]. The conversion of furfural yields both furfuryl alcohol and furan via hydrogenation and C-C bond cleavage, followed by sequential hydrogenation to tetrahydrofurfuryl alcohol and tetrahydrofuran. In addition to tetrahydrofuran, n-butanol, n-butanal, ethanol and hydrocarbon also derive from furan conversion. Furthermore, 2-methyltetrahydrofuran, 2-pentanone, 2-pentanol and 1-pentanol are all the hydrogenation products of 2-methylfuran obtained from a cleavage of C-O bond. Sitthisa et al. carried out furfural HDO over supported metal catalysts under atmospheric pressure, indicating that the product distribution was strongly depended on the metal used in the catalyst. Butanal, butanol and butane were obtained by ring opening reaction on $\mathrm{Ni} / \mathrm{SiO}_{2}$ catalyst, while $\mathrm{Pd} / \mathrm{SiO}_{2}$ catalyzed the formation of furan by decarbonylation [40].

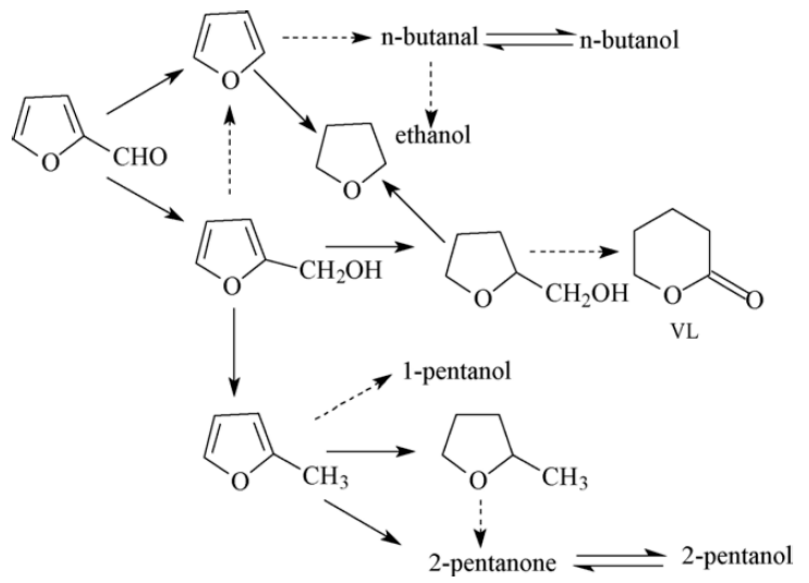

Figure 3. Proper reaction pathway proposed for furfural hydrogenation [39]. VL, $\delta$-valerolactone.

Conversion of carboxylic acids is crucial since they are considered as typical component that contribute to the corrosive property of bio-oil. Figure 4 shows the reaction network of aqueous phase 
hydrogenation of acetic acid proposed by Wan and co-workers [41]. Primary reaction of acetic acid includes dehydrogenation to acetate species or dehydroxylation to acetyl species. Acetate reacts further via decarboxylation or reforming to form $\mathrm{CH}_{4}$ or $\mathrm{H}_{2}$, respectively. Acetyls can either decompose via the cleavage of $\mathrm{C}-\mathrm{C}$ bond to $\mathrm{CH}_{4}$ and $\mathrm{CO}$ or be converted to ethanol. The formed ethanol is further converted to ethane via hydrodeoxygenation, $\mathrm{CH}_{4}$ via $\mathrm{C}-\mathrm{C}$ bond cleavage, and ethyl acetate via esterification. Moreover, $\mathrm{HDO}$ of acetic acid mixed with $p$-cresol was studied on $\mathrm{Ru} / \mathrm{C}$ catalyst at $573 \mathrm{~K}$ and 48 bar hydrogen pressure. In the mixed feed system, acetic acid hydrogenation was suppressed due to the competitive adsorption on catalyst surface. On the contrary, the HDO of $p$-cresol is promoted, resulting in high selectivity to methyl-cyclohexane.

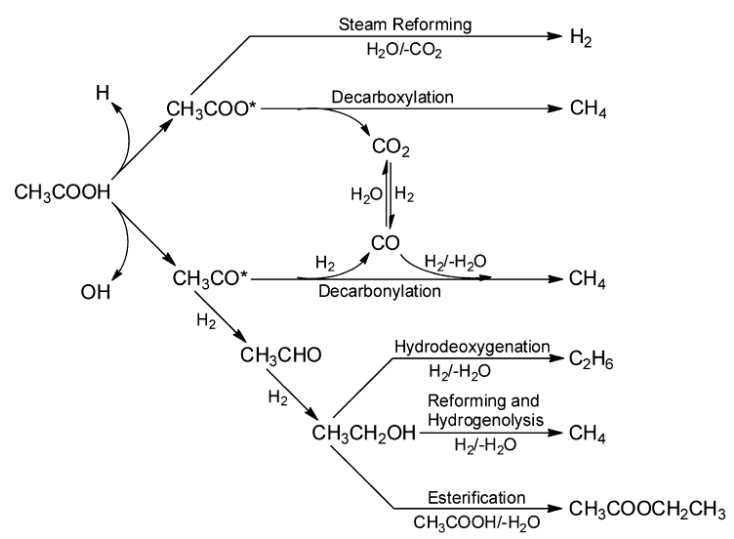

Figure 4. Proposed reaction network for aqueous phase hydrogenation of acetic acid [41].

Wildschut et al. selected D-glucose and D-cellobiose as model compounds for carbohydrates in bio-oil, and investigated the HDO of these monomeric sugars over Ru/C catalyst at $523 \mathrm{~K}$ and 100 bar $\mathrm{H}_{2}$ pressure. The main reaction pathway was D-sorbitol hydrogenation, followed by hydrogenolysis of smaller polyols (e.g., glycerol and propanediol) and gaseous hydrocarbon (e.g., methane and ethane). In addition to hydrogenation, a thermal pathway proceeded to form hydromethylfurfural, levulinic acid and humins. Furthermore, the study demonstrated that the acetic acid added in this system increased solids formation by promoting the thermal route [42].

\subsection{HDO of Actual Pyrolysis Oil}

Nemours studies focused on bio-oil hydrotreating to achieve liquid fuels compatible with petroleum fraction. Elliot et al. initially carried out HDO of poplar wood bio-oil over a sulfide CoMo catalyst in 1983. This direct hydrodeoxygenation yielded only $23 \mathrm{wt} \%$ upgraded oil and resulted in severe coke deposition and bed plugging [43]. Xiong et al. also tested direct HDO of bio-oil using a Raney Ni catalyst in a batch reactor, leading to low yield of organic liquid [44]. Therefore, in order to overcome the obstacles mentioned above, alternatives such as employing a two-stage process and co-feeding with solvents were investigated for bio-oil hydrotreatment.

\subsubsection{Two-Stage Hydrotreatment}

The two-stage process was initially carried out by researchers from Pacific Northwest National Laboratory (PNNL) in 1989 [45]. The first stage was operated below $553 \mathrm{~K}$ over Ni or sulfide CoMo catalyst to produce stabilized oil by hydrotreating the most reactive compound such as furans aldehydes, and ketones. The second step was performed at severe conditions in a second stage using conventional petroleum hydrotreating catalyst. With the two-stage hydrotreatment, the yield of upgraded oil could be increased to $30-55 \%$ with the comparison of direct HDO, and the deoxygenation degrees could be up to $99 \%$ [46]. Noble metal catalysts have also been applied to two-stage hydrotreatment by Elliot et al. It was demonstrated that $\mathrm{Pd} / \mathrm{C}$ was an effective catalyst to 
hydrogenate various bio-oils to stabilized oils suitable for more severe hydrocracking step. In the first hydrotreating step, the gas yield improved while the oil yield decreased at higher temperature, and the product oxygen contents reached the minimum level at $613 \mathrm{~K}$. The procedure could successfully run for 10 to $100 \mathrm{~h}$ depending on the operating conditions. Subsequent step were performed at about $673 \mathrm{~K}$ under 103 bar using a conventional sulfide catalyst, and the oxygen content of final products were all below $1 \%$. In addition to the configuration mentioned above, a non-isothermal system incorporating the two steps was further explored at 523-683 K under 138 bar. It was indicated that the non-isothermal configuration could effectively minimize the carbon loss leading to the higher oil yield (50\%) compared to the sequential one [47]. Gholizadeh et al. investigated the hydrotreament of mallee wood bio-oil in a non-isothermal configuration using $\mathrm{NiMo} / \gamma-\mathrm{Al}_{2} \mathrm{O}_{3}$ as main catalyst. The authors observed that the reaction temperature had a role in coke formation and quality of upgraded oil. Although $\mathrm{Pd} / \mathrm{C}$ catalyst laid in upstream had some effects on stabilizing bio-oil, it was ineffective in keeping off coke formation in long-term operation [48]. In order to increase catalyst lifetimes, PNNL partnered with Battelle developed a new process for bio-oil hydrotreatment based on a two-stage system. A cleanup step and ion exchange were performed before the first stabilization step, obtained the cleaned up bio-oil of which the contents of metallic impurities were obviously decreased. For the first reaction zone, non-carbon supported catalysts were employed and catalyst regeneration processes were developed. Therefore, the Battelle-PNNL bio-oil upgrading process is stable for over $1000 \mathrm{~h}$ time on stream [49].

\subsubsection{Co-Feeding Solvents}

Hydrogen donor solvents were widely used in the hydrogenation of coal liquids to remove the heteroatoms and decrease molecular weight. In order to facilitate the transformation of active hydrogen and reduce coke formation during HDO process, hydrogen donor solvents, such as tetralin and decalin, were used for bio-oil upgrading. Churin et al. investigated the influence of the presence of tetralin on hydrotreating of bio-oil over NiMo catalyst, indicating that the hydrogen donor resulted in an additional reduction in the oxygen content of $15 \%$ [50]. The oil phase of sawdust bio-oil was upgraded by Zhang et al. over sulfide Co-Mo-P, using tetralin and tar oil as solvent, respectively. The authors considered that tetralin transferred hydrogen from the gas phase with high activity to the radical fragments in oil phase, leading to higher liquid yield and less gas, char and water [51]. Zhang et al. used decalin as hydrogen donor in the hydrotreatment of bio-oil and its model compounds over $\mathrm{Ni} / \mathrm{TiO}_{2}-\mathrm{ZrO}_{2}$ at $573 \mathrm{~K}$. Higher reaction conversion was obtained when the initial $\mathrm{H}_{2}$ pressure increased, because the solubility of $\mathrm{H}_{2}$ in decalin was improved with the increased pressure [52]. Employing hydrogen donor solvent in bio-oil HDO significantly reduce the operating pressures and lighten charring and coking phenomena. Moreover, alkanes have also been used during bio-oil HDO. Zhao et al. investigated the HDO of n-hexane-extracted bio-oil over Ni/HZSM- 5 under mild reaction conditions. The obtained liquid products were almost hydrocarbons including $\mathrm{C} 5-\mathrm{C} 9$ alkanes, cycloalkanes, and aromatics molecules [53]. However, the hydrocarbon solvents cannot completely blend with crude bio-oil due to their hydrophobicity, which hinders the HDO reaction to some extent. Hence, supercritical solvents were used for bio-oil hydrotreating. Xu et al. selected 1-butanol as solvent in the supercritical upgrading of bio-oil over a $\mathrm{Ru} / \mathrm{C}$ catalyst, indicating that the features of upgraded bio-oil were significantly improved. The authors further illustrated that the solvent acted as both reaction medium and reactant during the reaction [54]. Oh et al. studied the HDO of bio-oil over Pt/C catalyst in the presence of three supercritical solvents with different polarities. The polar protic solvent (ethanol) efficiently improved the degree of deoxygenation and typical bio-oil properties, such as acidity, viscosity, HHV and water content, and the polar aprotic solvent (acetone) resulted in the highest yield of heavy oil. The non-polar ether hardly affected the organics, but improved its thermal stability [55].

\subsubsection{In-Situ Hydrogenation}

Recently, in-situ hydrogenation as a novel method using liquid hydrogenation donors instead of hydrogen gas attracted lots of interesting. Acids and alcohols are common hydrogenation 
donors, which can generate hydrogen via aqueous-phase reforming. Xiong et al. conducted an in-situ hydrogenation of rice husk bio-oil in the presence of formic acid over various metal catalysts. During the upgrading process, formic acid decomposed to produce hydrogen while by-product $\mathrm{CO}_{2}$ dissolved in solvents improving the rate of hydrogenation. High yield of liquid phase $(>86 \%)$ and slight coke formation $(<5 \%)$ were achieved with partial hydrogenation that alkenyl and aldehyde groups were almost completely reduced [44]. Xu et al. used methanol as hydrogen donor instead of hydrogen gas in the hydrogenation of bio-oil at $493 \mathrm{~K}$ and 30 bar. Over Raney Ni catalyst, ketones and aldehydes were converted to alcohols via in-situ hydrogenation, while esterification took place transforming acids to esters [56]. Furthermore, the authors carried out the upgrading process of bio-oil in different hydrogen donors (methanol, ethanol and formic acid) over Ni based catalysts to investigate the effect of hydrogen donors on the in-situ hydrogenation. The results showed that compositions of the upgraded bio-oils were different according to different hydrogen donors. When alcohols were used as hydrogen donors, the acetic acid in bio-oil could be converted to esters through esterification reaction. The phenol conversion was promoted in the presence of formic acid, along with restraining the conversion of acetic acid [57]. Currently, in-situ hydrogenation is not common for bio-oil upgrading due to its relative low hydrogenation degree leading to the intermediate hydrogenation products instead of hydrocarbons.

\section{HDO Catalysts}

\subsection{Transition Metal Sulfide Catalysts}

Conventional HDS catalysts for petroleum refining, using Mo as active component, $\mathrm{Co}$ or $\mathrm{Ni}$ as promoter, are first employed for the hydrogenation of pyrolysis oil. The HDO reactions catalyzed by metal sulfides are summarized in Table 4 . These HDS catalysts need to be kept in sulfide form, so a sulfur source like $\mathrm{H}_{2} \mathrm{~S}$ is commonly added during the reaction due to the negligible sulfur content of bio-oil. However, severe carbon deposition caused by sulfur leaching prohibits further application of petroleum hydrotreating catalysts. A number of suitable catalysts were investigated by researchers. Recently, Pawelec et al. contributed a review on the HDO of biomass derived liquids over transition metal sulfide catalysts [58]. This section focuses on the use of sulfide catalysts in HDO process.

Table 4. HDO catalyzed by metal sulfides.

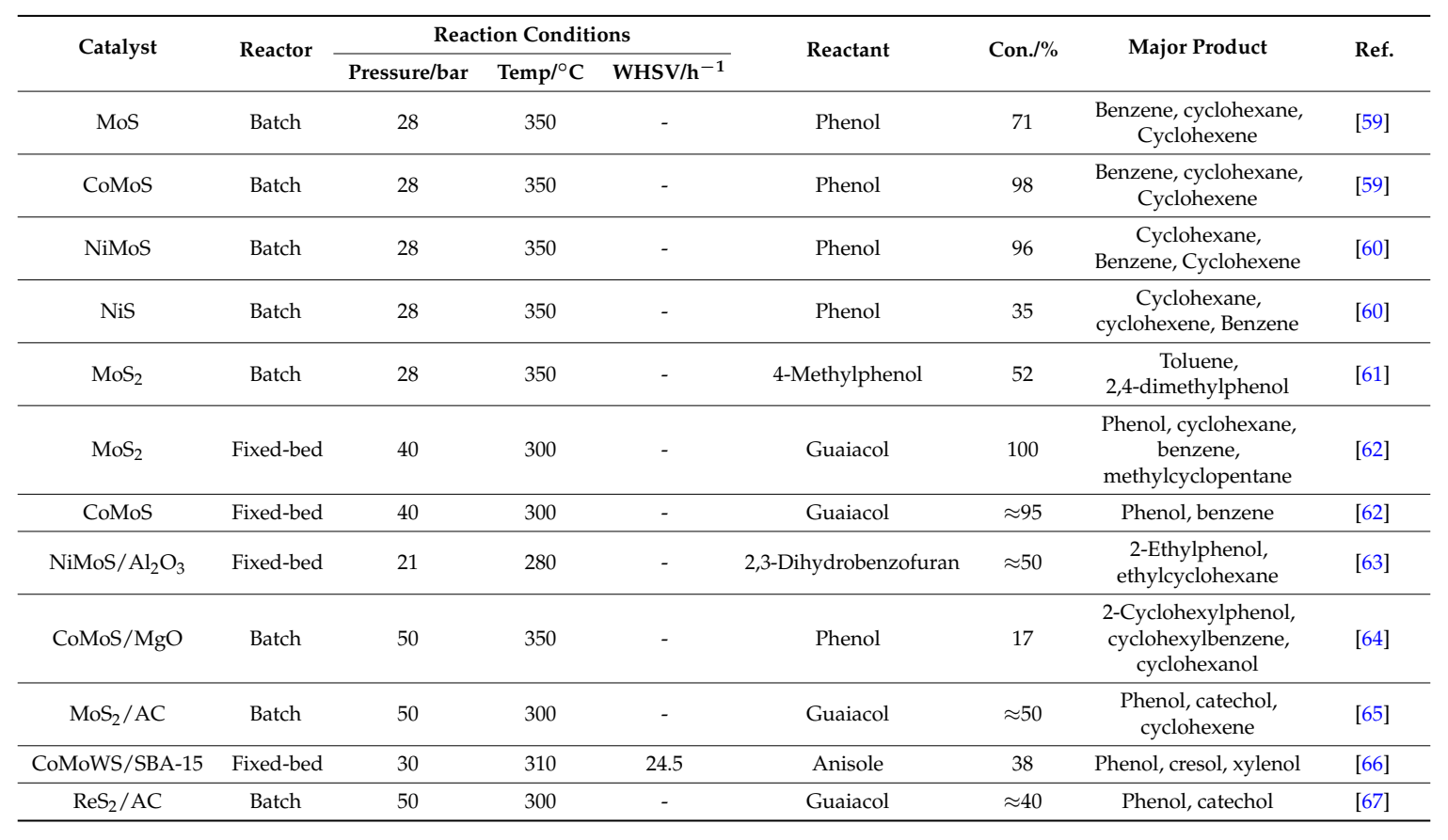


In an early investigation, sulfide CoMo and NiMo supported on $\gamma-\mathrm{A}_{2} \mathrm{O}_{3}$ were employed for HDO of carbonyl, carboxyl and guaiacyl groups. It is found that $\mathrm{NiMoS} / \gamma-\mathrm{A}_{2} \mathrm{O}_{3}$ showed higher decarboxylating activity compared to $\mathrm{CoMoS} / \gamma-\mathrm{A}_{2} \mathrm{O}_{3}$ and increased the content of heavy products in HDO process of guaiacol [68]. Massoth et al. carried out phenol HDO catalyzed by sulfide $\mathrm{CoMoS} / \mathrm{A1}_{2} \mathrm{O}_{3}$ at $573 \mathrm{~K}$ and 28.5 bar hydrogen pressure and obtained benzene, cyclohexene, cyclohexane and $\mathrm{H}_{2} \mathrm{O}$ as major products [69]. The mechanism of guaiacol $\mathrm{HDO}$ promoted by sulfide CoMo and $\mathrm{NiMo} / \mathrm{A}_{2} \mathrm{O}_{3}$ involved demethylation, demethoxylation and deoxygenation, followed by benzene ring saturation [70]. Compared with sulfide catalyst supported on $\mathrm{A}_{2} \mathrm{O}_{3}$, Nava et al. found that the activity of all the studied sulfide CoMo catalysts supported on mesoporous silicates were much higher. The selected mesoporous silicates included disordered mesoporous silica (DMS-1), hexagonal mesoporous silica (HMS) and cubic mesoporous silica (SBA-15, SBA-16). Among these four catalysts, CoMo/SBA-16 was considered as the most effective catalyst, indicating that the support morphology could strongly influence the catalytic response of catalysts [71]. Bui et al. investigated the effect of cobalt on $\mathrm{MoS}_{2}$ catalyst during the conversion of guaiacol. With addition of cobalt, the direct deoxygenation pathway involved in guaiacol conversion was obviously enhanced compared to the non-promoted $\mathrm{MoS}_{2}$, resulting in higher selectivity of aromatic hydrocarbons [62]. Yoosuk et al. compared the HDO activities of $\mathrm{MoS}_{2}, \mathrm{NiMoS}_{2}$ and $\mathrm{NiS}_{2}$ using phenol as a model substrate. They observed that $\mathrm{NiMoS}_{2}$ were more active than either of the other two catalysts and the maximum synergy was observed at a Ni/(Mo $+\mathrm{Ni})$ molar ratio of 0.3 [60]. Several unsupported $\mathrm{MoS}_{2}$ with different morphology were used by Yang et al for HDO of phenolic compounds. They found that was favored over $\mathrm{MoS}_{2}$ with a lower degree of stacking $\left(\mathrm{MoS}_{2}\right.$ derived from $\left.\mathrm{AHM}\right)$ facilitated the $\mathrm{C}-\mathrm{OH}$ bond hydrogenolysis, whereas $\mathrm{MoS}_{2}$ with a higher degree of stacking (exfoliated $\mathrm{MoS}_{2}$ ) facilitated aromatic ring hydrogenation [61].

\subsection{Noble Metal Catalysts}

Noble metal catalysts such as $\mathrm{Pt}, \mathrm{Pd}, \mathrm{Rh}$ and $\mathrm{Ru}$ have high catalytic activities for hydrotreating and can obviously improve the $\mathrm{H} / \mathrm{C}$ ratio of pyrolysis oil. A large study showed that noble metal catalysts had high activities for HDO of pyrolysis oil. The effect of $\mathrm{Pt}$ on oxygen removal was better than NiMo and CoMo catalysts under the same conditions. However, high costs and difficult recovery limit the industrial application of noble metal catalysts. Recent studies about HDO catalyzed by noble metal catalysts are listed in Table 5.

For this series of zirconia-supported catalysts ( $\mathrm{Pd}, \mathrm{Pt}, \mathrm{Rh} / \mathrm{ZrO}_{2}$ ) studied by Arditanti et al., $\mathrm{Pd} / \mathrm{ZrO}_{2}$ gave the highest activity and $\mathrm{Rh} / \mathrm{ZrO}_{2}$ results least carbon deposition [72]. All these noble metal catalysts showed higher activities than conventional $\mathrm{CoMo} / \mathrm{Al}_{2} \mathrm{O}_{3}$. Zanuttini et al. carried out cresol deoxygenation with $\mathrm{Pt}-\mathrm{Al}_{2} \mathrm{O}_{3}$ catalysts at atmospheric pressure, observing that methylcyclohexane was the major product at low temperature, while toluene achieved its highest yield at $573 \mathrm{~K}$ [73]. The vapor-phase $\mathrm{HDO}$ of anisole over a bifunctional $\mathrm{Pt} / \mathrm{H} \beta$ catalyst was conducted by Zhu et al. at $673 \mathrm{~K}$ and atmospheric pressure showed that the major products were benzene, toluene and xylene. They found that the acidic function catalyzed transalkylation, meanwhile the metal function promoted both demethylation and hydrodeoxygenation. Thus, compared with H-Beta and $\mathrm{Pt} / \mathrm{SiO}_{2}$ catalysts, less phenolic compounds and saturated hydrocarbons were obtained on the bifunctional catalyst [74]. In addition, a similar result was carried out from the HDO of $m$-cresol over the bifunctional Pt/HBeta catalyst [75]. Dwiatmoko et al. performed HDO of phenolic monomers over Ru catalysts supported on five different carbon materials. Among these catalysts, Ru supported on multi-walled carbon nanotubes (Ru/MWCNT) exhibited the highest HDO activity, owing to high surface area of $\mathrm{Ru}$ and high external surface area of the MWCNT [76]. Lu et al. synthesized $\mathrm{TiO}_{2}$-modified $\mathrm{Pd} / \mathrm{SiO}_{2}$ catalyst $\left(\mathrm{Tix} \mathrm{Pd} / \mathrm{SiO}_{2}\right.$ ) for the conversion of guaiacol to investigate synergistic effect between $\mathrm{Ti}$ and $\mathrm{Pd}$. They reported that addition of $\mathrm{TiO}_{2}$ suppressed the sintering of $\mathrm{Pd}$ particles resulting in high conversion of guaiacol, and $\mathrm{TixPd} / \mathrm{SiO}_{2}$ showed deoxygenation activity while $\mathrm{Pd} / \mathrm{SiO}_{2}$ only exhibits hydrogenation activity [77]. Echeandia et al. compared the catalytic activities of 
Pd catalysts supported on different support (zeolite $\mathrm{HY}, \mathrm{Al}_{2} \mathrm{O}_{3}$ and $\mathrm{HY}-\mathrm{Al}_{2} \mathrm{O}_{3}$ ) for the $\mathrm{HDO}$ of phenol. The activity of $\mathrm{Pd} / 20 \% \mathrm{HY}$-Al was the largest, which could be attributed to $\mathrm{H}$-spillover phenomenon and a large Pd dispersion [78].

Table 5. HDO catalyzed by noble metal catalysts.

\begin{tabular}{|c|c|c|c|c|c|c|c|c|}
\hline \multirow{2}{*}{ Catalyst } & \multirow{2}{*}{ Reactor } & \multicolumn{3}{|c|}{ Reaction Conditions } & \multirow{2}{*}{ Reactant } & \multirow{2}{*}{ Con. $/ \%$} & \multirow{2}{*}{ Major Product } & \multirow{2}{*}{ Ref. } \\
\hline & & Pressure/bar & Temp. $/{ }^{\circ} \mathrm{C}$ & WHSV $/ h^{-1}$ & & & & \\
\hline $\mathrm{TixPd} / \mathrm{SiO}_{2}$ & Fixed-bed & 20 & 300 & 25 & guaiacol & 100 & $\begin{array}{c}\text { methoxycyclohexanol, } \\
\text { cyclohexanol, cyclohexane }\end{array}$ & [77] \\
\hline $\mathrm{Pt} / \mathrm{TiO}_{2}$ & Fixed-bed & 20 & 350 & 200 & Cresol & $\approx 82$ & $\begin{array}{l}\text { Cyclohexanol,3-methyl, } \\
\text { Cyclohexanone,3-methyl, } \\
\text { Cyclohexane, methyl }\end{array}$ & [79] \\
\hline $\mathrm{PtMo} / \mathrm{Al}_{2} \mathrm{O}_{3}$ & Fixed-bed & 5 & 250 & - & Cresol & $\approx 95$ & $\begin{array}{l}\text { Methylcyclohexane, } \\
\text { 3-methylcyclohexanol }\end{array}$ & [82] \\
\hline Pd/HZSM-5 & Batch & 20 & 200 & - & Cresol & 100 & Methylcyclohexane & [83] \\
\hline $\mathrm{Pt} / \mathrm{H} \beta$ & Fixed-bed & 1 & 350 & 2 & Cresol & 100 & Toluene & {$[84]$} \\
\hline $\mathrm{Ru} / \mathrm{ZrO}_{2}$ & Fixed-bed & 64 & 200 & 1 & Propanoic acid & 94 & Ethane, propane, methane & [85] \\
\hline $\mathrm{Ru} / \mathrm{Al}_{2} \mathrm{O}_{3}$ & Fixed-bed & 64 & 200 & 1 & Propanoic acid & 58 & Propanol, propane, ethane & [85] \\
\hline $\mathrm{Ru} / \mathrm{C}$ & Fixed-bed & 64 & 190 & 1 & Propanoic acid & 94 & Ethane, methane, propane & [85] \\
\hline $\mathrm{Pt} / \mathrm{MgO}$ & Fixed-bed & 1 & 300 & 11 & Guaiacol & 6 & $\begin{array}{l}\text { Phenol, catechol, } \\
\text { cyclopentanone }\end{array}$ & [86] \\
\hline $\mathrm{Pt} / \mathrm{MZ}-5^{\mathrm{c}}$ & Fixed-bed & 40 & 200 & 6 (LHSV) & Dibenzofuran & 98 & $\begin{array}{c}\text { Bicyclohexyl, } \\
\text { Cyclopentylmethyl-cyclohexane }\end{array}$ & [87] \\
\hline Pt-Sn/CNF/Inconel ${ }^{d}$ & Fixed-bed & 1 & 400 & 0.3 & Guaiacol & 100 & Phenol, benzene & [88] \\
\hline $\mathrm{Pt} / \gamma-\mathrm{Al}_{2} \mathrm{O}_{3}$ & Fixed-bed & 1 & 300 & 20 & Guaiacol & $\approx 6$ & $\begin{array}{l}\text { Catechol, phenol, } \\
\text { 3-methylcatechol }\end{array}$ & [89] \\
\hline
\end{tabular}

a CARF means carbon aerogel; ${ }^{\mathrm{b}} \mathrm{MWCNT}$ means multi-walled carbon nanotubes; ${ }^{\mathrm{c}} \mathrm{MZ}-5$ means mesoporous ZSM-5; ${ }^{\mathrm{d}} \mathrm{CNF}$ means carbon nanofiber.

\subsection{Non-Noble Metal Catalysts}

Recently, non-noble metal catalysts including base metals, metal oxides, phosphides, carbides and nitrides are widely used for upgrading of bio-oil. Due to the low price of biomass feedstock, using noble catalysts in upgrading process is uneconomical. Therefore, HDO catalyzed by non-noble metal catalysts has drawn mounting attention. The HDO reactions catalyzed by non-noble metals are summarized in Table 6.

Mortensen et al. screened in total 23 catalysts for phenol HDO at $548 \mathrm{~K}$ and 100 bar, observing that $\mathrm{Ni}$ had the best performance among tested non-noble metal catalysts [93]. Compared with the high activity of oxide supported nickel catalysts, Ni/AC showed very low activity for phenol $\mathrm{HDO}$, proving that hydrogenation occurred on the oxidic support while deoxygenation took place on the crystallites. Interestingly, reverse result was obtained by Dongil et al. for the conversion of guaiacol over $\mathrm{Ni} / \mathrm{CNT}$ catalysts at 50 bar and $573 \mathrm{~K}$ in a batch reactor [94]. The guaiacol conversion could up to $100 \%$ yielding cyclohexanol, cyclohexane and methoxycyclohexanol as major products. These results means the property of support may also dramatically affect the HDO performances. Shafaghat and co-workers investigated the $\mathrm{HDO}$ of a phenolic mixture catalyzed by Ni/HBeta, $\mathrm{Fe} / \mathrm{HBeta}$ and NiFe/HBeta [95]. They observed that hydrogenation was the dominant pathway in 
producing cycloalkanes over $\mathrm{Ni} / \mathrm{HBeta}$, while aromatic hydrocarbons were mostly produced though hydrogenolysis over Fe/HBeta. The phenolic compounds catalyzed by NiFe/HBeta could be converted to both cycloalkanes and aromatic hydrocarbons due to the synergistic effect between $\mathrm{Ni}$ and $\mathrm{Fe}$. Olcese et al. compared the activity of $\mathrm{Fe} / \mathrm{SiO}_{2}$ and $\mathrm{Co} / \mathrm{Kieselguhr}$ for the gas phase $\mathrm{HDO}$ of guaiacol at 623-723 K [96]. They found that $\mathrm{Fe} / \mathrm{SiO}_{2}$ showed good selectivity to form aromatic hydrocarbons but did not exhibit activity for the hydrogenation of the aromatic ring. The n-electrons of the oxygen atoms are more basic than the $\pi$-electrons of $\mathrm{C}=\mathrm{C}$ aromatic system, so the $\mathrm{O}$ atoms in hydroxyl or methoxyl groups were adsorpted on the weak acidic $\mathrm{OH}$ sites. Subsequently, $\mathrm{C}-\mathrm{O}$ cleavage was catalyzed by the active $\mathrm{H}$-species coming from the dissociation of hydrogen molecules on the iron particles. Metallic oxide also been investigated as catalyst for bio-oil upgrading. Selvaraj et al. considered HDO of guaiacol over $\mathrm{MoO}_{3}-\mathrm{NiO} /$ mesoporous silicates at atmospheric pressure, observing the following order of $\mathrm{HDO}$ activities: $\mathrm{MoO}_{3}-\mathrm{NiO} / \mathrm{MAS}$ (mesoporous aluminosilicate) $>\mathrm{MoO}_{3}-\mathrm{NiO} / \mathrm{Ti}-\mathrm{SBA}-15$ $>\mathrm{MoO}_{3}-\mathrm{NiO} / \mathrm{SBA}-15$ [97]. However, naphthenic hydrocarbon was the major product over $\mathrm{MoO}_{3}-\mathrm{NiO} / \mathrm{MAS}$ compared to other catalysts, where and aromatic hydrocarbon was the major product. The effect of support on the catalytic activity was also investigated by Loricera and co-workers. $\mathrm{ZnNi} / \mathrm{Ti}\left(\mathrm{TiO}_{2}\right), \mathrm{ZnNi} / 2 \mathrm{Ti}-\mathrm{Si}$ (hybrid $2 \mathrm{TiO}_{2}-\mathrm{SiO}_{2}$ ), $\mathrm{ZnNi} / \mathrm{S} 15$ (SBA-15) and $\mathrm{ZnNi} / \mathrm{Ti}-\mathrm{S} 15$ (SBA-15 decorated with $\mathrm{TiO}_{2}$ ) were used for the HDO of phenol [98]. It was found that large BET surface area and acidity of supports were conducive to improving the catalytic efficiency. Ghampson et al. investigated $\mathrm{ReO}_{x}$ supported on oxidized carbon nanofiber $\left(\mathrm{ReO}_{x}-\mathrm{CNFox}\right)$ to catalyze phenol HDO at $573 \mathrm{~K}$, finding that phenol was completely converted at $10 \% \mathrm{ReO}_{\mathrm{x}}$ loading [99]. The coordinatively unsaturated $\mathrm{Re}^{4+}$, which acts as a Lewis acid, interacts with the oxygen lone pair on phenol. The C-1 of phenol accepts $\mathrm{H}^{+}$from surface hydroxyl groups resulting in an adsorbed phenoxide ion. After that, benzene was produced though $\mathrm{C}-\mathrm{O}$ bond cleavage and the recovery of the oxygen vacancy were accomplished by the elimination of water.

Metal carbides have attracted great attention as hydroprocessing catalysts since tungsten carbide (WC) was proved to have Pt-like property [100]. Frühberger and Chen also reported that surface modified by carbon converts the reactivity of Mo to that of Pt-group metals [101]. In particular, the catalytic activity of metal carbides can approach or surpass that of Pt-group metals in reaction like hydrogenation and dehydrogenation [102]. Lee et al. investigated the vapor-phase HDO of anisole catalyzed by $\mathrm{Mo}_{2} \mathrm{C}$ at $420-520 \mathrm{~K}$ under ambient pressure, in which benzene selectivity was up to $90 \%$ and cyclohexane selectivity was lower than $9 \%$ [103]. Chen et al. further obtained high yields of benzene and toluene from $\mathrm{HDO}$ of phenolic mixtures over $\mathrm{Mo}_{2} \mathrm{C}$ catalyst at $533-553 \mathrm{~K}$ and atmospheric hydrogen pressure. It is demonstrated that $\mathrm{Ar}-\mathrm{OCH}_{3}$ in guaiacol was cleaved prior to the $\mathrm{Ar}-\mathrm{OH}$, and the low selectivity for saturated hydrocarbons (e.g., cyclohexane and methylcyclohexane) was due to in-situ modification of $\mathrm{Mo}_{2} \mathrm{C}$ surface by oxygenates [104]. Recently, Lu et al. synthesized two ordered mesoporous metal carbides, $\mathrm{Mo}_{2} \mathrm{C}$ and $\mathrm{W}_{2} \mathrm{C}$, to investigated the conversion of anisole in gas-phase at relatively low temperatures (423-443 K) [105]. Mesoporous $\mathrm{W}_{2} \mathrm{C}$ catalyst showed a highest benzene selectivity reported to date $(\sim 96 \%)$ in anisole HDO, ascribed to the stronger oxygen affinity of tungsten and stronger $\mathrm{W}-\mathrm{O}$ bond in comparison to the $\mathrm{Mo}-\mathrm{O}$ bond. Metal nitrides have also drawn interest as candidate catalysts for hydrotreating bio-oil because of the coexistence of acidic and basic sites on nitrides caused by electronegativity differences between the metal and nitrogen atoms [106]. Currently, few researchers work on metal nitrides catalysts for bio-oil upgrading. Ghampson et al. considered the effect of $\mathrm{Mo}_{2} \mathrm{~N}$ on the conversion of guaiacol at $573 \mathrm{~K}$ and 50 bar hydrogen pressure in a batch reactor, finding that $\mathrm{Mo}_{2} \mathrm{~N}$ was the most active compared to $\mathrm{Mo}_{2} \mathrm{~N}_{0.78}$ and other molybdenum compounds [107]. Moreover, the addition of cobalt produced higher yields of deoxygenated products than $\mathrm{Mo}_{2} \mathrm{~N}$ due to the presence of $\mathrm{Co}_{3} \mathrm{Mo}_{3} \mathrm{~N}$ particles. HDO of guaiacol catalyzed by $\mathrm{Mo}_{2} \mathrm{~N}$ catalysts supported on activated carbons with different textural and chemical properties was studied by Sepúlveda and co-workers [108]. The $\mathrm{Mo}_{2} \mathrm{~N} / \mathrm{Norit}$ catalyst exhibited highest activity relative to $\mathrm{Mo}_{2} \mathrm{~N} / \mathrm{Cudu}$ and $\mathrm{Mo}_{2} \mathrm{~N} /$ Pica, because the high mesoporosity of Norit carbon facilitated reactant diffusion to the internal surfaces. $\mathrm{Mo}_{2} \mathrm{~N} /$ Norit also displayed 
higher phenol/catechol ratio than other catalysts. Metal carbides, nitrides and sulfides have similar preparation method. Generally, the starting materials of Mo-based catalysts are $\mathrm{MoO}_{3}$ or its precursor (e.g., ammonium heptamolybdate). $\mathrm{Mo}_{2} \mathrm{C}, \mathrm{Mo}_{2} \mathrm{~N}, \mathrm{MoS}_{2}$ could be prepared with pretreatment in $\mathrm{CH}_{4} / \mathrm{CO} / \mathrm{C}_{3} \mathrm{H}_{8}, \mathrm{NH}_{3}$ and $\mathrm{H}_{2} \mathrm{~S}$ flow, respectively [109-111]. Saito and Anderson compared the activities of these three catalysts with different pretreatments, indicating that $\mathrm{Mo}_{2} \mathrm{C}$ and $\mathrm{Mo}_{2} \mathrm{~N}$ had similar adsorbability of hydrogen, which was three times higher than that of $\mathrm{MoS}_{2}$ [111].

Due to the ensemble and/or ligand effects of $\mathrm{P}$, transition-metal phosphides exhibit high activity as hydrotreating catalysts and have drawn great attention for bio-oil upgrading [112]. Bui et al. synthesized a series of metal phosphides supported on $\mathrm{SiO}_{2}$ to investigate the catalytic activity on conversions of 2-methyltetrahydrofuran at $573 \mathrm{~K}$ and 1 bar. The HDO activities decreased in the sequence of $\mathrm{Ni}_{2} \mathrm{P}>\mathrm{WP}>\mathrm{MoP}>\mathrm{CoP}>\mathrm{FeP}$ and the selectivity toward $\mathrm{HDO}$ products followed the order of $\mathrm{MoP}>\mathrm{WP}>\mathrm{Ni}_{2} \mathrm{P}>\mathrm{FeP}>\mathrm{CoP}$ (phosphite method) and $\mathrm{MoP} \sim \mathrm{WP}>\mathrm{FeP}>\mathrm{Ni}_{2} \mathrm{P}>\mathrm{CoP}$ (phosphate method) [113]. An investigation of the anisole $\mathrm{HDO}$ catalyzed by $\mathrm{Ni}_{2} \mathrm{P} / \mathrm{SiO}_{2}, \mathrm{MoP} / \mathrm{SiO}_{2}$, and $\mathrm{NiMoP} / \mathrm{SiO}_{2}$ with different $\mathrm{Ni} / \mathrm{Mo}$ ratios led to the conclusion that $\mathrm{Ni}_{2} \mathrm{P}$ exhibit superior activity to that of MoP and the coexistent $\mathrm{Ni}$ and Mo could facilitate the phosphides dispersion. Three major products, phenol, benzene and cyclohexane, were obtained via demethylation, hydrogenolysis, and hydrogenation, and both metal sites and $\mathrm{PO}-\mathrm{H}$ groups were active for these reactions [112].

\subsection{Catalyst Deactivation}

Catalyst deactivation is an obvious problem in HDO, which means loss of catalyst activity as the reaction progress. Catalyst deactivation can be caused by coking, sintering, poisoning, and metal deposition. Catalysts properties are influenced with the degree of these phenomena. Especially, carbon deposition is known as the major cause of HDO catalysts deactivation. Polymerization and polycondensation are considered as main reactions leading to coke formation due to the obvious difference between the average molecular weight of coke and those present in the feeds. Therefore, the adsorbed reactants have a significant effect on the degree of carbon deposition. Unsaturated oxygenates in bio-oil, especially phenols and furans, are regarded as the predominant coke precursors since they can strongly interact with the catalytic surface [114]. Moreover, it has been reported that double-oxygen compounds were much more prone to coke formation than single-oxygen compounds [115]. The HDO of anisole and guaiacol conducted by González-Borja and Resasco also suggested that more severe catalyst deactivation was observed with guaiacol relative to anisole [88]. In addition to reactant structures, catalyst properties such as acidity play an important role in coke formation. In the study for HDO of guaiacol over CoMoS catalysts, Bui et al. reported the conventional alumina support obviously induced the formation of heavier products resulting in catalyst deactivation, while supports with less acidity $\left(\mathrm{ZrO}_{2}\right.$ and $\left.\mathrm{TiO}_{2}\right)$ formed less heavy by-products [116]. Meanwhile, it is proposed that Lewis acid sites bind reactant species adsorb to catalyst surface, and Brønsted acid sites supply protons to form carbocations as coke precursors [114]. Zanuttini et al. confirmed that $\mathrm{Pt} / \mathrm{SiO}_{2}$ had higher carbon deposition in the $\mathrm{HDO}$ of m-cresol compared to $\mathrm{Pt} / \mathrm{Al}_{2} \mathrm{O}_{3}$ due to the presence of Brønsted acid sites on silica supported catalyst, while alumina catalyst only had Lewis acid sites [117]. Therefore, the contribution of the Lewis and Brønsted acidic sites to coke formation is still debatable. Operating conditions such as temperature, $\mathrm{H}_{2}$ pressure and contact time are also relevant to coke formation during hydroprocessing. Low $\mathrm{H}_{2}$ pressure and reaction temperature tend to promote coke formation reactions rather than hydrogenation reaction. Li et al. studied the effect of reaction temperature on coke formation, finding that increased temperature caused severe coke formation despite the improvement of HDO extent [118]. 
Table 6. HDO catalyzed by non-noble metal catalysts.

\begin{tabular}{|c|c|c|c|c|c|c|c|c|}
\hline \multirow{2}{*}{ Catalyst } & \multirow{2}{*}{ Reactor } & \multicolumn{3}{|c|}{ Reaction Condition } & \multirow{2}{*}{ Reactant } & \multirow{2}{*}{ Con. $/ \%$} & \multirow{2}{*}{ Major Product } & \multirow{2}{*}{ Ref. } \\
\hline & & Pressure/bar & Temp./K & WHSV/h $\mathrm{h}^{-1}$ & & & & \\
\hline $\mathrm{Fe} / \mathrm{Ni} / \mathrm{H} \beta$ & Fixed-bed & 1 & $573-723$ & $0.25 \sim 0.4$ & Guaiacol & 100 & Phenol & [119] \\
\hline $\mathrm{ReOx} / \mathrm{CNF}^{\mathrm{a}}$ & Batch & 30 & 573 & - & Phenol & 100 & Cyclohexane, benzene & [99] \\
\hline $\mathrm{Ni} / \mathrm{CNT}^{\mathrm{b}}$ & Batch & 50 & 573 & - & Guaiacol & 100 & $\begin{array}{c}\text { Cyclohexane, } \\
\text { cyclohexanol, } \\
\text { Methoxycyclohexanol }\end{array}$ & [94] \\
\hline $\mathrm{Ni}_{2} \mathrm{P} / \mathrm{Al}_{2} \mathrm{O}_{3} @ \mathrm{TiO}_{2}$ & Fixed-bed & 30 & - & 4 & Benzofuran & 95 & $\begin{array}{l}\text { Ethylcyclohexane, } \\
\text { ethylbenzene, } \\
\text { methylcyclohexane }\end{array}$ & [120] \\
\hline $\mathrm{NiCu} / \mathrm{CNT}^{\mathrm{b}}$ & Batch & 50 & 573 & - & Guaiacol & 100 & $\begin{array}{c}\text { Cyclohexanol, } \\
\text { Cyclohexane, } \\
\text { Methoxycyclohexanol }\end{array}$ & [121] \\
\hline $\mathrm{Ni}_{2} \mathrm{P} / \mathrm{Al}-\mathrm{SBA}-15$ & Batch & 40 & 493 & - & Phenol & $\approx 100$ & Cyclohexane & [122] \\
\hline $\mathrm{Co}_{2} \mathrm{P} / \mathrm{Al}-\mathrm{SBA}-15$ & Batch & 40 & 493 & - & Phenol & 83 & $\begin{array}{l}\text { Cyclohexanol, } \\
\text { Cyclohexane }\end{array}$ & [122] \\
\hline MoP/Al-SBA-15 & Batch & 40 & 493 & - & Phenol & $\approx 20$ & $\begin{array}{c}\text { Cyclohexanone, } \\
\text { benzene, Cyclohexane }\end{array}$ & [122] \\
\hline Ni/Al-MCM-41 & Fixed-bed & 1 & 673 & 0.6 & Guaiacol & $\approx 100$ & Methane & [123] \\
\hline Co/Al-MCM-41 & Fixed-bed & 1 & 673 & 0.6 & Guaiacol & $\approx 100$ & $\begin{array}{l}\text { Benzene, phenol, } \\
\text { methane }\end{array}$ & [123] \\
\hline $\mathrm{Mo}_{2} \mathrm{C} / \mathrm{CNF}^{\mathrm{a}}$ & Batch & 55 & 623 & - & Guaiacol & $>99$ & Phenol, cresol & [124] \\
\hline Meso- $\mathrm{W}_{2} \mathrm{C}$ & Fixed-bed & 1 & 343 & - & Anisole & $\approx 2$ & Benzene & [105] \\
\hline $\mathrm{W}_{2} \mathrm{C} / \mathrm{CNF}^{\mathrm{a}}$ & Batch & 55 & 623 & - & Guaiacol & 66 & Phenol, cresol & [124] \\
\hline $\mathrm{MoO}_{3}$ & Fixed-bed & 1 & 593 & $\approx 0.2$ & Guaiacol & 98 & $\begin{array}{l}\text { Benzene, phenol, } \\
\text { anisole, toluene }\end{array}$ & [125] \\
\hline $\mathrm{NiCu} / \mathrm{ZrO}_{2}-\mathrm{SiO}_{2}$ & Batch & 50 & 613 & - & Guaiacol & 91 & $\begin{array}{c}\text { Cyclohexane, benzene, } \\
\text { catechol, }\end{array}$ & [126] \\
\hline $\mathrm{Ni} / \mathrm{SiO}_{2}-\mathrm{ZrO}_{2}$ & Batch & 50 & 573 & - & Guaiacol & 100 & $\begin{array}{l}\text { Cyclohexane, } \\
\text { Cyclohexene }\end{array}$ & [127] \\
\hline $\mathrm{Fe} / \mathrm{SiO}_{2}$ & Fixed-bed & 1 & 673 & 0.67 & Guaiacol & 100 & $\begin{array}{l}\text { Methane, phenol, } \\
\text { benzene }\end{array}$ & [96] \\
\hline $\mathrm{Ni} / \mathrm{CeO}_{2}$ & Batch & 100 & 548 & - & Phenol & 100 & Cyclohexanol & [93] \\
\hline $\mathrm{Ni} / \mathrm{MgAl}_{2} \mathrm{O}_{4}$ & Batch & 100 & 548 & - & Phenol & 100 & $\begin{array}{l}\text { Cyclohexanol, } \\
\text { cyclohexane }\end{array}$ & [93] \\
\hline $\mathrm{NiMoP} / \mathrm{Al}_{2} \mathrm{O}_{3}$ & Fixed-bed & 70 & 613 & - & Benzofuran & 48 & $\begin{array}{c}\text { 2-Ethylphenol, } \\
\text { 2,3-dihydrobenzofuran }\end{array}$ & [128] \\
\hline $\mathrm{Ni} / \mathrm{Cr}_{2} \mathrm{O}_{3}$ & Fixed-bed & 10 & 573 & 6 (LHSV) & Anisole & 90.2 & cyclohexane & [129] \\
\hline $\mathrm{Ni}-\mathrm{Cu} / \mathrm{CeO}_{2}$ & Fixed-bed & 10 & 523 & 1 (LHSV) & Anisole & 100 & cyclohexane & [129] \\
\hline $\mathrm{Ni}-\mathrm{W}(\mathrm{Si})^{\mathrm{c}}$ & Fixed-bed & 15 & 523 & 0.5 & Phenol & 100 & cyclohexane & [130] \\
\hline $\mathrm{Ni}-\mathrm{W}(\mathrm{P})^{\mathrm{d}}$ & Fixed-bed & 15 & 523 & 0.5 & Phenol & 100 & cyclohexane & [130] \\
\hline
\end{tabular}

\section{Conclusions}

Although the hydrogenation technology applied for pyrolysis oil has been developed for decades, some problems still exist that clog the development of this technology. (1) High cost and low hydrogen efficiency: HDO process can improve the pyrolysis oil quality, but it generally has low hydrogen utilization efficiency. Now, a better way to optimize the process is the combination of different hydrogen production to supply operations such as two-stage hydrodeoxygenation and in situ hydrogenation. The combination of these operations lowers the operation cost and produces more high value chemicals. (2) Complexity of operation process: In order to make the system work continuously, solid particles in pyrolysis oil have to be removed. Downstream treatment after hydrodeoxygenation is required to remove water to lower the water content in the meantime. Another vital operation unit is hydrogen regeneration unit, which can decrease the hydrogen consumption. Due to the process in whole system is complex, effectively simplify the operation system can dramatically lower the cost and make it easy to enlarge the system. (3) Proper catalyst and catalytic system: One of the key research 
subjects is to find out suitable catalysts. Noble metals are considered as a kind of efficient catalysts if its high cost is not taken into consideration.

These problems we summarized have hindered further development of biomass pyrolysis oil for a long time. However, with the development of modern analysis instruments and new generation technology, we believe there will be some breakthrough in this area. (1) Understanding the composition of biomass pyrolysis oil: Since biomass pyrolysis oil is a mixture of organic compounds, the properties of these components are complex, and molecular weight distribution is also very wide. FT-ICR, NMR and GC $\times$ GC have been proven as powerful analysis methods to identify different groups, of which conventional GC/MS can only provide limited information about these components. MS is the most common way to identify chemicals in biomass research. Considering the conditions of pyrolysis oil, a soft ionization mass spectrum is a better choice to identify mixtures. With the rapid development of new mass spectrum, it gives us a better understanding about both organic and inorganic components. (2) Understanding pyrolysis chemistry: Compared to other solid feedstock, biomass pyrolysis is a more complex process since it contains many $\mathrm{O}$ atoms. Thus, it is a big challenge to understand its pyrolysis pathways. Researchers designed different experiments to study the pyrolysis chemistry. Generally speaking, biomass pyrolysis contains two stage reactions. Thus, understanding the two stage reactions and their interactions are extremely of great value for pyrolyzer design and downstream processes. (3) Catalyst and catalytic process design: A high efficient catalyst and catalytic process is the core of pyrolysis oil upgrading. Transitional metal carbides were proved to act like noble metals, which may give us a series of low cost catalyst systems which can work at low hydrogen pressure. A good design of catalytic process should be based on both catalytic reactions and interaction between reactions. Since different pyrolysis compositions have dramatically different properties and transform pathway, synergy effect of different components should be considered during the designation.

In this review, we summarized recent progress in biomass pyrolysis oil upgrading to hydrocarbon fuels, mainly focusing on hydrodeoxygenation process. Although biomass pyrolysis oil upgrading research has been developing for decades, problems still exist as the bottleneck for further industrialization. Herein, we proposed our solutions: with the usage of modern analysis technology to understand the pyrolysis intermediates and product distribution, a more precise reaction network should be developed which is extremely useful to understand what will be converted. With the help of more precisely understanding on upstream composition, high activity and selectivity catalysts can be designed. In addition, source of coke formation and effect of alkaline salt are profitable to extend the life-span of catalyst. Based on selected catalyst, a better catalytic process will be designed for large scale industrialization.

Acknowledgments: This work was supported by NSFC (Natural Science Foundation of China) project (51476175 and 51606205), national basic research program of china (2013CB228105), Chinese Academy of Sciences "one hundred talented plan", and Beijing Municipal Key Discipline of Biomass Engineering.

Author Contributions: Zhan Si carried out the literature collection and the manuscript writing; Chenguang Wang supervised the study and partially wrote the introduction and conclusion; Xinghua Zhang and Renjie Dong proofread the paper; and Longlong Ma proposed the review topics.

Conflicts of Interest: The authors declare no conflict of interest.

\section{References}

1. Huber, G.W.; Iborra, S.; Corma, A. Synthesis of transportation fuels from biomass: Chemistry, catalysts, and engineering. Chem. Rev. 2006, 106, 4044-4098. [CrossRef] [PubMed]

2. Vispute, T.P.; Zhang, H.; Sanna, A.; Xiao, R.; Huber, G.W. Renewable chemical commodity feedstocks from integrated catalytic processing of pyrolysis oils. Science 2010, 330, 1222-1227. [CrossRef] [PubMed]

3. Zhang, J.; Nolte, M.W.; Shanks, B.H. Investigation of primary reactions and secondary effects from the pyrolysis of different celluloses. ACS Sustain. Chem. Eng. 2014, 2, 2820-2830. [CrossRef]

4. Bridgwater, A.V. Review of fast pyrolysis of biomass and product upgrading. Biomass Bioenergy 2012, 38, 68-94. [CrossRef] 
5. Sipilä, K.; Kuoppala, E.; Fagernäs, L.; Oasmaa, A. Characterization of biomass-based flash pyrolysis oils. Biomass Bioenergy 1998, 14, 103-113. [CrossRef]

6. Onay, O. Influence of pyrolysis temperature and heating rate on the production of bio-oil and char from safflower seed by pyrolysis, using a well-swept fixed-bed reactor. Fuel Process. Technol. 2007, 88, 523-531. [CrossRef]

7. Oasmaa, A.; Solantausta, Y.; Arpiainen, V.; Kuoppala, E.; Sipilä, K. Fast pyrolysis bio-oils from wood and agricultural residues. Energy Fuels 2009, 24, 1380-1388. [CrossRef]

8. Lu, Q.; Yang, X.-L.; Zhu, X.-F. Analysis on chemical and physical properties of bio-oil pyrolyzed from rice husk. J. Anal. Appl. Pyrolysis 2008, 82, 191-198. [CrossRef]

9. Yildiz, G.; Ronsse, F.; Venderbosch, R.; van Duren, R.; Kersten, S.R.; Prins, W. Effect of biomass ash in catalytic fast pyrolysis of pine wood. Appl. Catal. B Environ. 2015, 168, 203-211. [CrossRef]

10. Kubička, D.; Horáček, J. Deactivation of hds catalysts in deoxygenation of vegetable oils. Appl. Catal. A Gen. 2011, 394, 9-17. [CrossRef]

11. Scahill, J.; Diebold, J.; Feik, C. Removal of residual char fines from pyrolysis vapors by hot gas filtration. In Developments in Thermochemical Biomass Conversion; Springer: Dordrecht, The Netherlands, 1997; pp. $253-266$.

12. Pattiya, A.; Suttibak, S. Production of bio-oil via fast pyrolysis of agricultural residues from cassava plantations in a fluidised-bed reactor with a hot vapour filtration unit. J. Anal. Appl. Pyrolysis 2012, 95, 227-235. [CrossRef]

13. Baldwin, R.M.; Feik, C.J. Bio-oil stabilization and upgrading by hot gas filtration. Energy Fuels 2013, 27, 3224-3238. [CrossRef]

14. Jung, S.-H.; Kang, B.-S.; Kim, J.-S. Production of bio-oil from rice straw and bamboo sawdust under various reaction conditions in a fast pyrolysis plant equipped with a fluidized bed and a char separation system. J. Anal. Appl. Pyrolysis 2008, 82, 240-247. [CrossRef]

15. Park, H.J.; Dong, J.-I.; Jeon, J.-K.; Park, Y.-K.; Yoo, K.-S.; Kim, S.-S.; Kim, J.; Kim, S. Effects of the operating parameters on the production of bio-oil in the fast pyrolysis of japanese larch. Chem. Eng. J. 2008, 143, 124-132. [CrossRef]

16. Tessarolo, N.S.; Silva, R.V.; Vanini, G.; Casilli, A.; Ximenes, V.L.; Mendes, F.L.; de Rezende Pinho, A.; Romão, W.; de Castro, E.V.; Kaiser, C.R. Characterization of thermal and catalytic pyrolysis bio-oils by high-resolution techniques: ${ }^{1} \mathrm{H}-\mathrm{NMR}, \mathrm{GC} \times$ GC-TOFMS and FT-ICR MS. J. Anal. Appl. Pyrolysis 2016, 117, 257-267. [CrossRef]

17. Wang, S.-R.; Luo, Z.-Y.; Tan, H.; Hong, J.; Dong, L.-J.; Fang, M.-X.; Cen, K.-F. The analyses of characteristics of bio-oil produced from biomass by flash pyrolysis. J. Eng. Thermophys. 2004, 25, 1049-1052.

18. Tessarolo, N.S.; dos Santos, L.R.; Silva, R.S.; Azevedo, D.A. Chemical characterization of bio-oils using comprehensive two-dimensional gas chromatography with time-of-flight mass spectrometry. J. Chromatogr. A 2013, 1279, 68-75. [CrossRef] [PubMed]

19. Tessarolo, N.S.; Silva, R.C.; Vanini, G.; Pinho, A.; Romão, W.; de Castro, E.V.; Azevedo, D.A. Assessing the chemical composition of bio-oils using ft-icr mass spectrometry and comprehensive two-dimensional gas chromatography with time-of-flight mass spectrometry. Microchem. J. 2014, 117, 68-76. [CrossRef]

20. Jarvis, J.M.; McKenna, A.M.; Hilten, R.N.; Das, K.; Rodgers, R.P.; Marshall, A.G. Characterization of pine pellet and peanut hull pyrolysis bio-oils by negative-ion electrospray ionization fourier transform ion cyclotron resonance mass spectrometry. Energy Fuels 2012, 26, 3810-3815. [CrossRef]

21. Liu, Y.; Shi, Q.; Zhang, Y.; He, Y.; Chung, K.H.; Zhao, S.; Xu, C. Characterization of red pine pyrolysis bio-oil by gas chromatography-mass spectrometry and negative-ion electrospray ionization fourier transform ion cyclotron resonance mass spectrometry. Energy Fuels 2012, 26, 4532-4539. [CrossRef]

22. Mullen, C.A.; Strahan, G.D.; Boateng, A.A. Characterization of various fast-pyrolysis bio-oils by NMR spectroscopy. Energy Fuels 2009, 23, 2707-2718. [CrossRef]

23. Staš, M.; Kubička, D.; Chudoba, J.; Pospíšil, M. Overview of analytical methods used for chemical characterization of pyrolysis bio-oil. Energy Fuels 2014, 28, 385-402. [CrossRef]

24. Shafaghat, H.; Rezaei, P.S.; Daud, W.M.A.W. Effective parameters on selective catalytic hydrodeoxygenation of phenolic compounds of pyrolysis bio-oil to high-value hydrocarbons. RSC Adv. 2015, 5, 103999-104042. [CrossRef]

25. Zhao, C.; He, J.; Lemonidou, A.A.; Li, X.; Lercher, J.A. Aqueous-phase hydrodeoxygenation of bio-derived phenols to cycloalkanes. J. Catal. 2011, 280, 8-16. [CrossRef] 
26. Resasco, D.E.; Crossley, S.P. Implementation of concepts derived from model compound studies in the separation and conversion of bio-oil to fuel. Catal. Today 2015, 257, 185-199. [CrossRef]

27. Hong, D.-Y.; Miller, S.J.; Agrawal, P.K.; Jones, C.W. Hydrodeoxygenation and coupling of aqueous phenolics over bifunctional zeolite-supported metal catalysts. Chem. Commun. 2010, 46, 1038-1040. [CrossRef] [PubMed]

28. Sankaranarayanan, T.M.; Berenguer, A.; Ochoa-Hernández, C.; Moreno, I.; Jana, P.; Coronado, J.M.; Serrano, D.P.; Pizarro, P. Hydrodeoxygenation of anisole as bio-oil model compound over supported $\mathrm{Ni}$ and Co catalysts: Effect of metal and support properties. Catal. Today 2015, 243, 163-172. [CrossRef]

29. Pichaikaran, S.; Arumugam, P. Vapour phase hydrodeoxygenation of anisole over ruthenium and nickel supported mesoporous aluminosilicate. Green Chem. 2016, 18, 2888-2899. [CrossRef]

30. Nguyen, T.-S.; Laurenti, D.; Afanasiev, P.; Konuspayeva, Z.; Piccolo, L. Titania-supported gold-based nanoparticles efficiently catalyze the hydrodeoxygenation of guaiacol. J. Catal. 2016, 344, 136-140. [CrossRef]

31. Zhao, H.; Li, D.; Bui, P.; Oyama, S. Hydrodeoxygenation of guaiacol as model compound for pyrolysis oil on transition metal phosphide hydroprocessing catalysts. Appl. Catal. A Gen. 2011, 391, 305-310. [CrossRef]

32. Mullen, C.A.; Boateng, A.A. Characterization of water insoluble solids isolated from various biomass fast pyrolysis oils. J. Anal. Appl. Pyrolysis 2011, 90, 197-203. [CrossRef]

33. Bayerbach, R.; Meier, D. Characterization of the water-insoluble fraction from fast pyrolysis liquids (pyrolytic lignin). Part IV: Structure elucidation of oligomeric molecules. J. Anal. Appl. Pyrolysis 2009, 85, 98-107. [CrossRef]

34. Jongerius, A.L.; Jastrzebski, R.; Bruijnincx, P.C.; Weckhuysen, B.M. Como sulfide-catalyzed hydrodeoxygenation of lignin model compounds: An extended reaction network for the conversion of monomeric and dimeric substrates. J. Catal. 2012, 285, 315-323. [CrossRef]

35. Zhang, W.; Chen, J.; Liu, R.; Wang, S.; Chen, L.; Li, K. Hydrodeoxygenation of lignin-derived phenolic monomers and dimers to alkane fuels over bifunctional zeolite-supported metal catalysts. ACS Sustain. Chem. Eng. 2014, 2, 683-691. [CrossRef]

36. Parsell, T.H.; Owen, B.C.; Klein, I.; Jarrell, T.M.; Marcum, C.L.; Haupert, L.J.; Amundson, L.M.; Kenttämaa, H.I.; Ribeiro, F.; Miller, J.T. Cleavage and hydrodeoxygenation (HDO) of C-O bonds relevant to lignin conversion using pd/zn synergistic catalysis. Chem. Sci. 2013, 4, 806-813. [CrossRef]

37. Strassberger, Z.; Alberts, A.H.; Louwerse, M.J.; Tanase, S.; Rothenberg, G. Catalytic cleavage of lignin $\beta$-O-4 link mimics using copper on alumina and magnesia-alumina. Green Chem. 2013, 15, 768-774. [CrossRef]

38. Furimsky, E. The mechanism of catalytic hydrodeoxygenation of furan. Appl. Catal. 1983, 6, 159-164. [CrossRef]

39. Zheng, H.-Y.; Zhu, Y.-L.; Teng, B.-T.; Bai, Z.-Q.; Zhang, C.-H.; Xiang, H.-W.; Li, Y.-W. Towards understanding the reaction pathway in vapour phase hydrogenation of furfural to 2-methylfuran. J. Mol. Catal. A Chem. 2006, 246, 18-23. [CrossRef]

40. Sitthisa, S.; Resasco, D.E. Hydrodeoxygenation of furfural over supported metal catalysts: A comparative study of Cu, Pd and Ni. Catal. Lett. 2011, 141, 784-791. [CrossRef]

41. Wan, H.; Chaudhari, R.V.; Subramaniam, B. Aqueous phase hydrogenation of acetic acid and its promotional effect on $p$-cresol hydrodeoxygenation. Energy Fuels 2012, 27, 487-493. [CrossRef]

42. Wildschut, J.; Arentz, J.; Rasrendra, C.; Venderbosch, R.; Heeres, H. Catalytic hydrotreatment of fast pyrolysis oil: Model studies on reaction pathways for the carbohydrate fraction. Environ. Prog. Sustain. Energy 2009, 28, 450-460. [CrossRef]

43. Elliott, D.; Baker, E. Biomass Liquefaction Product Analysis and Upgrading; Pacific Northwest Lab: Richland, WA, USA, 1983.

44. Xiong, W.-M.; Fu, Y.; Zeng, F.-X.; Guo, Q.-X. An in situ reduction approach for bio-oil hydroprocessing. Fuel Process. Technol. 2011, 92, 1599-1605. [CrossRef]

45. Elliott, D.C.; Baker, E.G. Process for Upgrading Biomass Pyrolyzates. U.S. Patent 4795841, 1 March 1989.

46. Wildschut, J.; Mahfud, F.H.; Venderbosch, R.H.; Heeres, H.J. Hydrotreatment of fast pyrolysis oil using heterogeneous noble-metal catalysts. Ind. Eng. Chem. Res. 2009, 48, 10324-10334. [CrossRef]

47. Elliott, D.C.; Hart, T.R.; Neuenschwander, G.G.; Rotness, L.J.; Zacher, A.H. Catalytic hydroprocessing of biomass fast pyrolysis bio-oil to produce hydrocarbon products. Environ. Prog. Sustain. Energy 2009, 28, 441-449. [CrossRef]

48. Gholizadeh, M.; Gunawan, R.; Hu, X.; de Miguel Mercader, F.; Westerhof, R.; Chaitwat, W.; Hasan, M.M.; Mourant, D.; Li, C.-Z. Effects of temperature on the hydrotreatment behaviour of pyrolysis bio-oil and coke formation in a continuous hydrotreatment reactor. Fuel Process. Technol. 2016, 148, 175-183. [CrossRef] 
49. DOE Bioenergy Technologies Office (BETO) 2015 Project Peer Review. Available online: https://www. energy.gov/sites/prod/files/2015/04/f21/thermochemical_conversion_abdullah_231401.pdf (accessed on 28 October 2016).

50. Churin, E.; Maggi, R.; Grange, P.; Delmon, B. Characterization and upgrading of a bio-oil produced by pyrolysis of biomass. In Research in Thermochemical Biomass Conversion; Springer: Berlin, Germany, 1988; pp. 896-909.

51. Zhang, S.; Yan, Y.; Li, T.; Ren, Z. Upgrading of liquid fuel from the pyrolysis of biomass. Bioresour. Technol. 2005, 96, 545-550. [CrossRef] [PubMed]

52. Zhang, X.; Long, J.; Kong, W.; Zhang, Q.; Chen, L.; Wang, T.; Ma, L.; Li, Y. Catalytic upgrading of bio-oil over Ni-based catalysts supported on mixed oxides. Energy Fuels 2014, 28, 2562-2570. [CrossRef]

53. Zhao, C.; Lercher, J.A. Upgrading pyrolysis oil over Ni/HZSM-5 by cascade reactions. Angew. Chem. 2012, 124, 6037-6042. [CrossRef]

54. Xu, X.; Zhang, C.; Zhai, Y.; Liu, Y.; Zhang, R.; Tang, X. Upgrading of bio-oil using supercritical 1-butanol over a Ru/C heterogeneous catalyst: Role of the solvent. Energy Fuels 2014, 28, 4611-4621. [CrossRef]

55. Oh, S.; Kim, U.-J.; Choi, I.-G.; Choi, J.W. Solvent effects on improvement of fuel properties during hydrodeoxygenation process of bio-oil in the presence of Pt/C. Energy 2016, 113, 116-123. [CrossRef]

56. Xu, Y.; Long, J.; Liu, Q.; Li, Y.; Wang, C.; Zhang, Q.; Lv, W.; Zhang, X.; Qiu, S.; Wang, T. In situ hydrogenation of model compounds and raw bio-oil over raney Ni catalyst. Energy Convers. Manag. 2015, 89, $188-196$. [CrossRef]

57. Xu, Y.; Li, Y.; Wang, C.; Wang, C.; Ma, L.; Wang, T.; Zhang, X.; Zhang, Q. In-situ hydrogenation of model compounds and raw bio-oil over Mi/CMK-3 catalyst. Fuel Process. Technol. 2016, 161, 226-231. [CrossRef]

58. Rinaldi, R. Catalytic Hydrogenation for Biomass Valorization; Royal Society of Chemistry: London, UK, 2014.

59. Yoosuk, B.; Tumnantong, D.; Prasassarakich, P. Unsupported $\mathrm{MoS}_{2}$ and $\mathrm{CoMoS}_{2}$ catalysts for hydrodeoxygenation of phenol. Chem. Eng. Sci. 2012, 79, 1-7. [CrossRef]

60. Yoosuk, B.; Tumnantong, D.; Prasassarakich, P. Amorphous unsupported Ni-Mo sulfide prepared by one step hydrothermal method for phenol hydrodeoxygenation. Fuel 2012, 91, 246-252. [CrossRef]

61. Yang, Y.Q.; Tye, C.T.; Smith, K.J. Influence of $\mathrm{MoS}_{2}$ catalyst morphology on the hydrodeoxygenation of phenols. Catal. Commun. 2008, 9, 1364-1368. [CrossRef]

62. Bui, V.N.; Laurenti, D.; Afanasiev, P.; Geantet, C. Hydrodeoxygenation of guaiacol with CoMo catalysts. Part I: Promoting effect of cobalt on HDO selectivity and activity. Appl. Catal. B Environ. 2011, 101, $239-245$. [CrossRef]

63. Bunch, A.Y.; Ozkan, U.S. Investigation of the reaction network of benzofuran hydrodeoxygenation over sulfided and reduced Ni-Mo/ $\mathrm{Al}_{2} \mathrm{O}_{3}$ catalysts. J. Catal. 2002, 206, 177-187. [CrossRef]

64. Yang, Y.; Gilbert, A.; Xu, C.C. Hydrodeoxygenation of bio-crude in supercritical hexane with sulfided CoMo and CoMoP catalysts supported on MgO: A model compound study using phenol. Appl. Catal. A Gen. 2009, 360, 242-249. [CrossRef]

65. Ruiz, P.; Frederick, B.; De Sisto, W.; Austin, R.; Radovic, L.; Leiva, K.; García, R.; Escalona, N.; Wheeler, M. Guaiacol hydrodeoxygenation on $\mathrm{MoS}_{2}$ catalysts: Influence of activated carbon supports. Catal. Commun. 2012, 27, 44-48. [CrossRef]

66. Loricera, C.; Pawelec, B.; Infantes-Molina, A.; Álvarez-Galván, M.; Huirache-Acuña, R.; Nava, R.; Fierro, J.L.G. Hydrogenolysis of anisole over mesoporous sulfided CoMoW/SBA-15 (16) catalysts. Catal. Today 2011, 172, 103-110. [CrossRef]

67. Sepúlveda, C.; García, R.; Reyes, P.; Ghampson, I.; Fierro, J.L.G.; Laurenti, D.; Vrinat, M.; Escalona, N. Hydrodeoxygenation of guaiacol over $\mathrm{ReS}_{2}$ /activated carbon catalysts. Support and re loading effect. Appl. Catal. A Gen. 2014, 475, 427-437. [CrossRef]

68. Laurent, E.; Delmon, B. Study of the hydrodeoxygenation of carbonyl, carboxylic and guaiacyl groups over sulfided $\mathrm{CoMo} / \gamma-\mathrm{Al}_{2} \mathrm{O}_{3}$ and $\mathrm{NiMo} / \gamma-\mathrm{Al}_{2} \mathrm{O}_{3}$ catalysts: I. Catalytic reaction schemes. Appl. Catal. A Gen. 1994, 109, 77-96. [CrossRef]

69. Massoth, F.; Politzer, P.; Concha, M.; Murray, J.; Jakowski, J.; Simons, J. Catalytic hydrodeoxygenation of methyl-substituted phenols: Correlations of kinetic parameters with molecular properties. J. Phys. Chem. B 2006, 110, 14283-14291. [CrossRef] [PubMed]

70. Lin, Y.-C.; Li, C.-L.; Wan, H.-P.; Lee, H.-T.; Liu, C.-F. Catalytic hydrodeoxygenation of guaiacol on Rh-based and sulfided CoMo and NiMo catalysts. Energy Fuels 2011, 25, 890-896. [CrossRef] 
71. Nava, R.; Pawelec, B.; Castaño, P.; Álvarez-Galván, M.; Loricera, C.; Fierro, J.L.G. Upgrading of bio-liquids on different mesoporous silica-supported CoMo catalysts. Appl. Catal. B Environ. 2009, 92, 154-167. [CrossRef]

72. Ardiyanti, A.; Gutierrez, A.; Honkela, M.; Krause, A.; Heeres, H. Hydrotreatment of wood-based pyrolysis oil using zirconia-supported mono-and bimetallic (Pt, Pd, Rh) catalysts. Appl. Catal. A Gen. 2011, 407, 56-66. [CrossRef]

73. Zanuttini, M.; Lago, C.; Querini, C.; Peralta, M. Deoxygenation of $m$-cresol on $\mathrm{Pt} / \gamma-\mathrm{Al}_{2} \mathrm{O}_{3}$ catalysts. Catal. Today 2013, 213, 9-17. [CrossRef]

74. Zhu, X.; Lobban, L.L.; Mallinson, R.G.; Resasco, D.E. Bifunctional transalkylation and hydrodeoxygenation of anisole over a Pt/HBeta catalyst. J. Catal. 2011, 281, 21-29. [CrossRef]

75. Zhu, X.; Nie, L.; Lobban, L.L.; Mallinson, R.G.; Resasco, D.E. Efficient conversion of $m$-cresol to aromatics on a bifunctional Pt/HBeta catalyst. Energy Fuels 2014, 28, 4104-4111. [CrossRef]

76. Dwiatmoko, A.A.; Zhou, L.; Kim, I.; Choi, J.-W.; Suh, D.J.; Ha, J.-M. Hydrodeoxygenation of lignin-derived monomers and lignocellulose pyrolysis oil on the carbon-supported Ru catalysts. Catal. Today 2016, 265, 192-198. [CrossRef]

77. Lu, M.; Zhu, J.; Li, M.; Shan, Y.; He, M.; Song, C. $\mathrm{TiO}_{2}$-modified $\mathrm{Pd} / \mathrm{SiO}_{2}$ for catalytic hydrodeoxygenation of guaiacol. Energy Fuels 2016, 30, 6671-6676. [CrossRef]

78. Echeandia, S.; Pawelec, B.; Barrio, V.; Arias, P.; Cambra, J.; Loricera, C.; Fierro, J.L.G. Enhancement of phenol hydrodeoxygenation over Pd catalysts supported on mixed $\mathrm{HY}$ zeolite and $\mathrm{Al}_{2} \mathrm{O}_{3}$. An approach to O-removal from bio-oils. Fuel 2014, 117, 1061-1073. [CrossRef]

79. Griffin, M.B.; Ferguson, G.A.; Ruddy, D.A.; Biddy, M.J.; Beckham, G.T.; Schaidle, J.A. Role of the support and reaction conditions on the vapor-phase deoxygenation of $m$-cresol over $\mathrm{Pt} / \mathrm{C}$ and $\mathrm{Pt} / \mathrm{TiO}_{2}$ catalysts. ACS Catal. 2016, 6, 2715-2727. [CrossRef]

80. Yang, J.; Li, S.; Zhang, L.; Liu, X.; Wang, J.; Pan, X.; Li, N.; Wang, A.; Cong, Y.; Wang, X. Hydrodeoxygenation of furans over $\mathrm{Pd}-\mathrm{FeO}_{\mathrm{x}} / \mathrm{SiO}_{2}$ catalyst under atmospheric pressure. Appl. Catal. B Environ. 2017, 201, $266-277$. [CrossRef]

81. Xu, G.-Y.; Guo, J.-H.; Qu, Y.-C.; Zhang, Y.; Fu, Y.; Guo, Q.-X. Selective hydrodeoxygenation of lignin-derived phenols to alkyl cyclohexanols over a Ru-solid base bifunctional catalyst. Green Chem. 2016, 18, 5510-5517. [CrossRef]

82. Robinson, A.; Ferguson, G.A.; Gallagher, J.R.; Cheah, S.; Beckham, G.T.; Schaidle, J.A.; Hensley, J.E.; Medlin, J.W. Enhanced hydrodeoxygenation of $m$-cresol over bimetallic Pt-Mo catalysts through an oxophilic metal-induced tautomerization pathway. ACS Catal. 2016, 6, 4356-4368. [CrossRef]

83. Hunns, J.A.; Arroyo, M.; Lee, A.F.; Serrano, D.; Wilson, K. Hierarchical mesoporous Pd/ZSM-5 for the selective catalytic hydrodeoxygenation of $m$-cresol to methylcyclohexane. Catal. Sci. Technol. 2016, 6, 2560-2564. [CrossRef]

84. Sun, Q.; Chen, G.; Wang, H.; Liu, X.; Han, J.; Ge, Q.; Zhu, X. Insights into the major reaction pathways of vapor-phase hydrodeoxygenation of $m$-cresol on a Pt/HBeta catalyst. ChemCatChem 2016, 8, 551-561. [CrossRef]

85. Chen, L.; Zhu, Y.; Zheng, H.; Zhang, C.; Zhang, B.; Li, Y. Aqueous-phase hydrodeoxygenation of carboxylic acids to alcohols or alkanes over supported Ru catalysts. J. Mol. Catal. A Chem. 2011, 351, 217-227. [CrossRef]

86. Nimmanwudipong, T.; Aydin, C.; Lu, J.; Runnebaum, R.C.; Brodwater, K.C.; Browning, N.D.; Block, D.E.; Gates, B.C. Selective hydrodeoxygenation of guaiacol catalyzed by platinum supported on magnesium oxide. Catal. Lett. 2012, 142, 1190-1196. [CrossRef]

87. Wang, Y.; Fang, Y.; He, T.; Hu, H.; Wu, J. Hydrodeoxygenation of dibenzofuran over noble metal supported on mesoporous zeolite. Catal. Commun. 2011, 12, 1201-1205. [CrossRef]

88. González-Borja, M.Á.; Resasco, D.E. Anisole and guaiacol hydrodeoxygenation over monolithic Pt-Sn catalysts. Energy Fuels 2011, 25, 4155-4162. [CrossRef]

89. Nimmanwudipong, T.; Runnebaum, R.C.; Block, D.E.; Gates, B.C. Catalytic conversion of guaiacol catalyzed by platinum supported on alumina: Reaction network including hydrodeoxygenation reactions. Energy Fuels 2011, 25, 3417-3427. [CrossRef]

90. Wawrzetz, A.; Peng, B.; Hrabar, A.; Jentys, A.; Lemonidou, A.; Lercher, J. Towards understanding the bifunctional hydrodeoxygenation and aqueous phase reforming of glycerol. J. Catal. 2010, 269, 411-420. [CrossRef] 
91. Lee, C.R.; Yoon, J.S.; Suh, Y.-W.; Choi, J.-W.; Ha, J.-M.; Suh, D.J.; Park, Y.-K. Catalytic roles of metals and supports on hydrodeoxygenation of lignin monomer guaiacol. Catal. Commun. 2012, 17, 54-58. [CrossRef]

92. Gutierrez, A.; Kaila, R.; Honkela, M.; Slioor, R.; Krause, A. Hydrodeoxygenation of guaiacol on noble metal catalysts. Catal. Today 2009, 147, 239-246. [CrossRef]

93. Mortensen, P.M.; Grunwaldt, J.-D.; Jensen, P.A.; Jensen, A.D. Screening of catalysts for hydrodeoxygenation of phenol as a model compound for bio-oil. ACS Catal. 2013, 3, 1774-1785. [CrossRef]

94. Dongil, A.; Ghampson, I.; García, R.; Fierro, J.L.G.; Escalona, N. Hydrodeoxygenation of guaiacol over $\mathrm{Ni} /$ carbon catalysts: Effect of the support and ni loading. RSC Adv. 2016, 6, 2611-2623. [CrossRef]

95. Shafaghat, H.; Rezaei, P.S.; Daud, W.M.A.W. Catalytic hydrodeoxygenation of simulated phenolic bio-oil to cycloalkanes and aromatic hydrocarbons over bifunctional metal/acid catalysts of Ni/HBeta, Fe/HBeta and $\mathrm{NiFe} / \mathrm{HBeta}$. J. Ind. Eng. Chem. 2016, 35, 268-276. [CrossRef]

96. Olcese, R.; Bettahar, M.; Petitjean, D.; Malaman, B.; Giovanella, F.; Dufour, A. Gas-phase hydrodeoxygenation of guaiacol over $\mathrm{Fe} / \mathrm{SiO}_{2}$ catalyst. Appl. Catal. B Environ. 2012, 115, 63-73. [CrossRef]

97. Selvaraj, M.; Shanthi, K.; Maheswari, R.; Ramanathan, A. Hydrodeoxygenation of guaiacol over $\mathrm{MoO}_{3}-\mathrm{NiO} /$ mesoporous silicates: Effect of incorporated heteroatom. Energy Fuels 2014, 28, 2598-2607. [CrossRef]

98. Loricera, C.; Castaño, P.; Infantes-Molina, A.; Hita, I.; Gutierrez, A.; Arandes, J.; Fierro, J.L.G.; Pawelec, B. Designing supported znni catalysts for the removal of oxygen from bio-liquids and aromatics from diesel. Green Chem. 2012, 14, 2759-2770. [CrossRef]

99. Ghampson, I.T.; Sepúlveda, C.; García, R.; Fierro, J.L.G.; Escalona, N. Carbon nanofiber-supported ReO ${ }_{x}$ catalysts for the hydrodeoxygenation of lignin-derived compounds. Catal. Sci. Technol. 2016, 6, 4356-4369. [CrossRef]

100. Levy, R.; Boudart, M. Platinum-like behavior of tungsten carbide in surface catalysis. Science 1973, 181, 547-549. [CrossRef] [PubMed]

101. Frühberger, B.; Chen, J. Reaction of ethylene with clean and carbide-modified Mo (110): Converting surface reactivities of molybdenum to Pt-group metals. J. Am. Chem. Soc. 1996, 118, 11599-11609. [CrossRef]

102. Hwu, H.H.; Chen, J.G. Surface chemistry of transition metal carbides. Chem. Rev. 2005, 105, $185-212$. [CrossRef] [PubMed]

103. Lee, W.-S.; Wang, Z.; Wu, R.J.; Bhan, A. Selective vapor-phase hydrodeoxygenation of anisole to benzene on molybdenum carbide catalysts. J. Catal. 2014, 319, 44-53. [CrossRef]

104. Chen, C.-J.; Lee, W.-S.; Bhan, A. $\mathrm{Mo}_{2} \mathrm{C}$ catalyzed vapor phase hydrodeoxygenation of lignin-derived phenolic compound mixtures to aromatics under ambient pressure. Appl. Catal. A Gen. 2016, 510, 42-48. [CrossRef]

105. Lu, Q.; Chen, C.-J.; Luc, W.; Chen, J.G.; Bhan, A.; Jiao, F. Ordered mesoporous metal carbides with enhanced anisole hydrodeoxygenation selectivity. ACS Catal. 2016, 6, 3506-3514. [CrossRef]

106. Saidi, M.; Samimi, F.; Karimipourfard, D.; Nimmanwudipong, T.; Gates, B.C.; Rahimpour, M.R. Upgrading of lignin-derived bio-oils by catalytic hydrodeoxygenation. Energy Environ. Sci. 2014, 7, 103-129. [CrossRef]

107. Ghampson, I.; Sepulveda, C.; Garcia, R.; Frederick, B.; Wheeler, M.; Escalona, N.; DeSisto, W. Guaiacol transformation over unsupported molybdenum-based nitride catalysts. Appl. Catal. A Gen. 2012, 413, 78-84. [CrossRef]

108. Sepúlveda, C.; Leiva, K.; García, R.; Radovic, L.; Ghampson, I.; DeSisto, W.; Fierro, J.L.G.; Escalona, N. Hydrodeoxygenation of 2-methoxyphenol over $\mathrm{Mo}_{2} \mathrm{~N}$ catalysts supported on activated carbons. Catal. Today 2011, 172, 232-239. [CrossRef]

109. Furimsky, E. Metal carbides and nitrides as potential catalysts for hydroprocessing. Appl. Catal. A Gen. 2003, 240, 1-28. [CrossRef]

110. Farag, H.; Sakanishi, K.; Kouzu, M.; Matsumura, A.; Sugimoto, Y.; Saito, I. Investigation of the influence of $\mathrm{H}_{2} \mathrm{~S}$ on hydrodesulfurization of dibenzothiophene over a bulk $\mathrm{MoS}_{2}$ catalyst. Ind. Eng. Chem. Res. 2003, 42, 306-310. [CrossRef]

111. Saito, M.; Anderson, R. The activity of several molybdenum compounds for the methanation of CO. J. Catal. 1980, 63, 438-446. [CrossRef]

112. Li, K.; Wang, R.; Chen, J. Hydrodeoxygenation of anisole over silica-supportedNi ${ }_{2} \mathrm{P}, \mathrm{MoP}$, and NiMoP catalysts. Energy Fuels 2011, 25, 854-863. [CrossRef] 
113. Bui, P.; Cecilia, J.A.; Oyama, S.T.; Takagaki, A.; Infantes-Molina, A.; Zhao, H.; Li, D.; Rodríguez-Castellón, E.; López, A.J. Studies of the synthesis of transition metal phosphides and their activity in the hydrodeoxygenation of a biofuel model compound. J. Catal. 2012, 294, 184-198. [CrossRef]

114. Furimsky, E.; Massoth, F.E. Deactivation of hydroprocessing catalysts. Catal. Today 1999, 52, $381-495$. [CrossRef]

115. Popov, A.; Kondratieva, E.; Goupil, J.M.; Mariey, L.; Bazin, P.; Gilson, J.-P.; Travert, A.; Maugé, F. Bio-oils hydrodeoxygenation: Adsorption of phenolic molecules on oxidic catalyst supports. J. Phys. Chem. C 2010, 114, 15661-15670. [CrossRef]

116. Bui, V.N.; Laurenti, D.; Delichère, P.; Geantet, C. Hydrodeoxygenation of guaiacol: Part II: Support effect for CoMoS catalysts on HDO activity and selectivity. Appl. Catal. B Environ. 2011, 101, 246-255. [CrossRef]

117. Zanuttini, M.; Dalla Costa, B.; Querini, C.; Peralta, M. Hydrodeoxygenation of $m$-cresol with Pt supported over mild acid materials. Appl. Catal. A Gen. 2014, 482, 352-361. [CrossRef]

118. Li, Y.; Zhang, C.; Liu, Y.; Hou, X.; Zhang, R.; Tang, X. Coke deposition on Ni/HZSM-5 in bio-oil hydrodeoxygenation processing. Energy Fuels 2015, 29, 1722-1728. [CrossRef]

119. Xu, X.; Jiang, E.; Du, Y.; Li, B. BTX from the gas-phase hydrodeoxygenation and transmethylation of guaiacol at room pressure. Renew. Energy 2016, 96, 458-468. [CrossRef]

120. Song, H.; Gong, J.; Song, H.-L.; Li, F.; Zhang, J.; Chen, Y.-G. Preparation of core-shell structured $\mathrm{Ni}_{2} \mathrm{P} / \mathrm{Al}_{2} \mathrm{O}_{3} @$ $\mathrm{TiO}_{2}$ and its hydrodeoxygenation performance for benzofuran. Catal. Commun. 2016, 85, 1-4. [CrossRef]

121. Dongil, A.; Bachiller-Baeza, B.; Rodriguez-Ramos, I.; Fierro, J.L.G.; Escalona, N. The effect of Cu loading on $\mathrm{Ni} /$ carbon nanotubes catalysts for hydrodeoxygenation of guaiacol. RSC Adv. 2016, 6, 26658-26667. [CrossRef]

122. Berenguer, A.; Sankaranarayanan, T.; Gómez, G.; Moreno, I.; Coronado, J.; Pizarro, P.; Serrano, D. Evaluation of transition metal phosphides supported on ordered mesoporous materials as catalysts for phenol hydrodeoxygenation. Green Chem. 2016, 18, 1938-1951. [CrossRef]

123. Tran, N.T.; Uemura, Y.; Ramli, A. Hydrodeoxygenation of guaiacol over Al-MCM-41 supported metal catalysts: A comparative study of Co and Ni. Procedia Eng. 2016, 148, 1252-1258. [CrossRef]

124. Jongerius, A.L.; Gosselink, R.W.; Dijkstra, J.; Bitter, J.H.; Bruijnincx, P.C.; Weckhuysen, B.M. Carbon nanofiber supported transition-metal carbide catalysts for the hydrodeoxygenation of guaiacol. ChemCatChem 2013, 5, 2964-2972. [CrossRef]

125. Prasomsri, T.; Shetty, M.; Murugappan, K.; Román-Leshkov, Y. Insights into the catalytic activity and surface modification of $\mathrm{MoO}_{3}$ during the hydrodeoxygenation of lignin-derived model compounds into aromatic hydrocarbons under low hydrogen pressures. Energy Environ. Sci. 2014, 7, 2660-2669. [CrossRef]

126. Zhang, X.; Wang, T.; Ma, L.; Zhang, Q.; Yu, Y.; Liu, Q. Characterization and catalytic properties of Ni and $\mathrm{NiCu}$ catalysts supported on $\mathrm{ZrO}_{2}-\mathrm{SiO}_{2}$ for guaiacol hydrodeoxygenation. Catal. Commun. 2013, 33, $15-19$. [CrossRef]

127. Zhang, X.; Zhang, Q.; Wang, T.; Ma, L.; Yu, Y.; Chen, L. Hydrodeoxygenation of lignin-derived phenolic compounds to hydrocarbons over $\mathrm{Ni} / \mathrm{SiO}_{2}-\mathrm{ZrO}_{2}$ catalysts. Bioresour. Technol. 2013, 134, 73-80. [CrossRef] [PubMed]

128. Romero, Y.; Richard, F.; Renème, Y.; Brunet, S. Hydrodeoxygenation of benzofuran and its oxygenated derivatives (2, 3-dihydrobenzofuran and 2-ethylphenol) over $\mathrm{NiMoP} / \mathrm{Al}_{2} \mathrm{O}_{3}$ catalyst. Appl. Catal. A Gen. 2009, 353, 46-53. [CrossRef]

129. Yakovlev, V.; Khromova, S.; Sherstyuk, O.; Dundich, V.; Ermakov, D.Y.; Novopashina, V.; Lebedev, M.Y.; Bulavchenko, O.; Parmon, V. Development of new catalytic systems for upgraded bio-fuels production from bio-crude-oil and biodiesel. Catal. Today 2009, 144, 362-366. [CrossRef]

130. Echeandia, S.; Arias, P.; Barrio, V.; Pawelec, B.; Fierro, J.L.G. Synergy effect in the HDO of phenol over Ni-W catalysts supported on active carbon: Effect of tungsten precursors. Appl. Catal. B Environ. 2010, 101, 1-12. [CrossRef]

(C) 2017 by the authors. Licensee MDPI, Basel, Switzerland. This article is an open access article distributed under the terms and conditions of the Creative Commons Attribution (CC BY) license (http://creativecommons.org/licenses/by/4.0/). 